Florida International University FIU Digital Commons

\title{
Sustainability Analysis of Domestic Rainwater Harvesting Systems for Current and Future Water Security in Rural Mexico
}

Elena E. Neibaur

Florida International University, eneib001@fiu.edu

DOI: $10.25148 /$ etd.FIDC000109

Follow this and additional works at: https:// digitalcommons.fiu.edu/etd

Part of the Natural Resources and Conservation Commons, Sustainability Commons, and the Water Resource Management Commons

\section{Recommended Citation}

Neibaur, Elena E., "Sustainability Analysis of Domestic Rainwater Harvesting Systems for Current and Future Water Security in Rural Mexico" (2015). FIU Electronic Theses and Dissertations. 2245.

https://digitalcommons.fiu.edu/etd/2245 


\section{FLORIDA INTERNATIONAL UNIVERSITY}

Miami, Florida

\section{SUSTAINABILITY ANALYSIS OF DOMESTIC RAINWATER HARVESTING SYSTEMS FOR CURRENT AND FUTURE WATER SECURITY IN RURAL MEXICO}

A thesis submitted in partial fulfillment of the requirements for the degree of MASTER OF SCIENCE

in

ENVIRONMENTAL STUDIES

by

Elena Espi Neibaur 
To: Dean Michael R. Heithaus

College of Arts and Sciences

This thesis, written by Elena Espi Neibaur, and entitled Sustainability Analysis of Domestic Rainwater Harvesting Systems for Current and Future Water Security in Rural Mexico, having been approved in respect to style and intellectual content, is referred to you for judgment.

We have read this thesis and recommend that it be approved.

$\begin{array}{r}\hline \text { Assefa Melesse } \\ \hline \text { David Bray } \\ \hline \text { Elizabeth Anderson, Major Professor }\end{array}$

Date of Defense: June 24, 2015

The thesis of Elena Espi Neibaur is approved.

\begin{tabular}{r} 
Dean Michael R. Heithaus \\
College of Arts and Sciences \\
\hline Dean Lakshmi N. Reddi \\
University Graduate School
\end{tabular}

Florida International University, 2015 


\section{ACKNOWLEDGMENTS}

The first person I would like to thank is my advisor, Dr. Elizabeth Anderson, for her continual support, guidance, and patience throughout the Peace Corps Master International Program. Over the years she has been a wonderful mentor and her confidence in my abilities helped push me to achieve the most out of my graduate career. I also want to thank my graduate committee members, Dr. Assefa Melesse and Dr. David Bray, who also contributed to my education and provided advice and support. Dr. Assefa Melesse helped to expand on my knowledge on various hydrological analytical methods. Dr. David Bray helped guide me in carrying out effective surveys as well as gave me helpful advice and recommendations based on his substantial experience working in Mexico. I would like to thank my Peace Corps counterpart Ismael Couto for his unfailing support of my Peace Corps work as well as my thesis throughout my service. The rainwater harvesting projects would not have been possible without his support of my grant proposals and his help in seeking additional financial aid. The rainwater harvesting projects were funded with USAID, Peace Corps Partnership Program, and Gender Equality and Temporary Employment Programs from Mexico's Federal Ministry of Environment and Natural Resources (SEMARNAT). I would like to thank the Mexican ministries, SMASP and SEMARNAT, for providing me information, feedback and support during my fieldwork. I wish to acknowledge Dr. Ernesto Mangas who guided me with technical tools and knowledge for water quality testing as well as allowing me to use his laboratory equipment and space freely. My gratitude also extends to Marce Leon in her assistance in facilitating information exchanges through various workshops in San Jose Xacxamayo. I would like to express my gratitude for Diego Rodrigo Bravo Pacheco, 
who helped and supported me throughout my whole Peace Corps service and provided his photography services to support the cause of helping the San Jose Xacxamayo have improved water security. This thesis would not be possible without the guidance and encouragement of my family and friends. I would like to thank my brother, Isaac Neibaur, who encouraged me to pursue the Master's International Program at Florida International University and has guided me along the way. I would like to acknowledge the Peace Corps staff and volunteers for supporting me in my projects and thesis development. Finally, I would like to express my appreciation and gratitude for the community members of San Jose Xacxamayo for their kindness, handwork, and dedication they put into these rainwater harvesting projects. In addition, they opened their doors and hearts that enabled me to successfully complete my thesis research. 


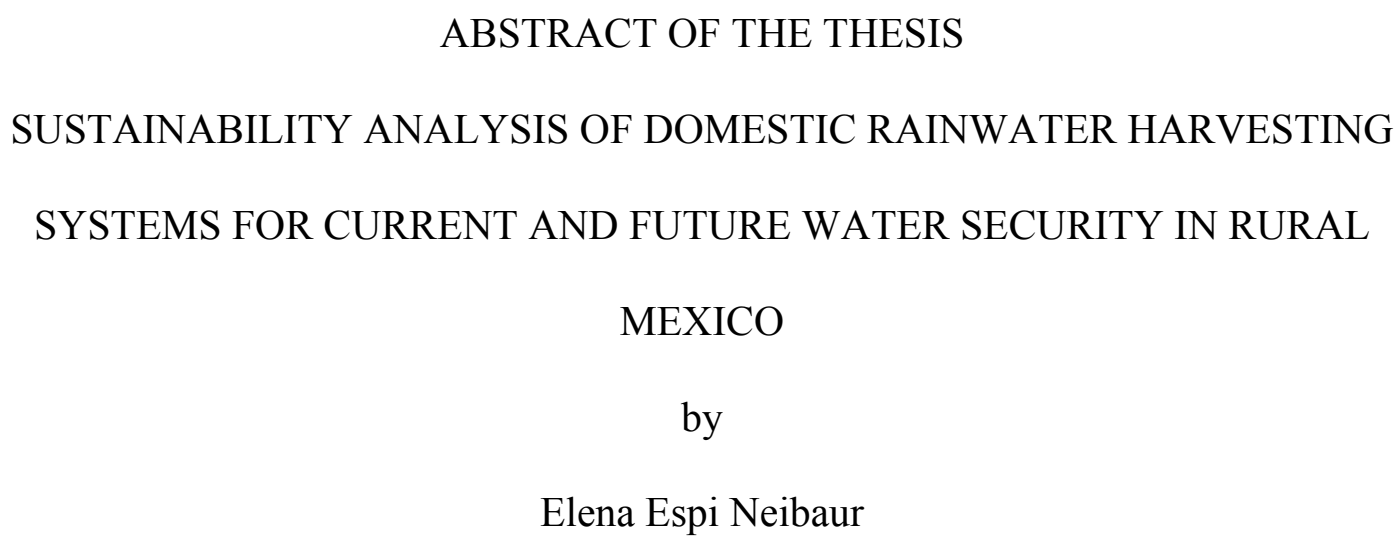

Florida International University, 2015

Miami, Florida

Professor Elizabeth Anderson, Major Professor

Rainwater harvesting, the act of capturing and storing rain, is an ancient practice that is increasingly utilized today by communities to address water supply needs. This thesis examines whether domestic rainwater harvesting systems (DRWHS) can be a sustainable solution as defined by social, water quality, and technical feasibility for water security in semi-arid, rural environments. For this study, 50 surveys and 17 stored rainwater analyses were conducted in San Jose Xacxamayo, Mexico, in conjunction with my Peace Corps work of implementing 82 DRWHS. Results showed that all DRWHS were socially feasible because of cultural acceptance and local capacity. Water quality analyses showed that four DRWHS contained coliform bacteria; deeming water unfit for human consumption. Technical feasibility, examined through climate analyses, showed an average year-round reliability of 20-30\% under current and future rainfall regime. The DRWHS can be a sustainable water supply option with roof expansion and treatment prior to consumption. 


\section{TABLE OF CONTENTS}

CHAPTER

PAGE

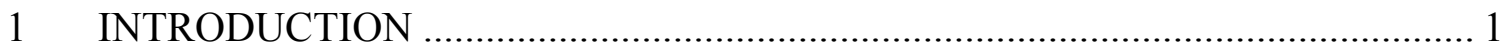

1.1 Peace Corps and Project Overview …………................................................... 1

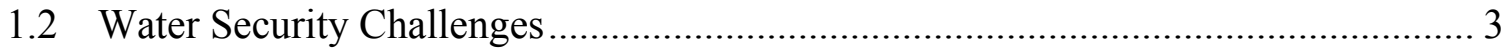

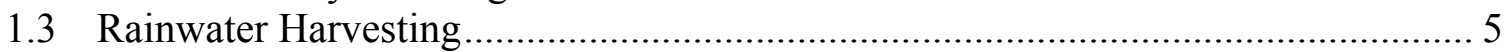

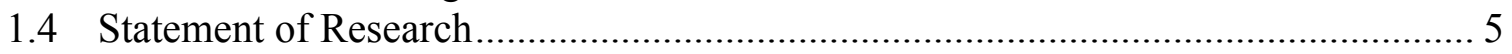

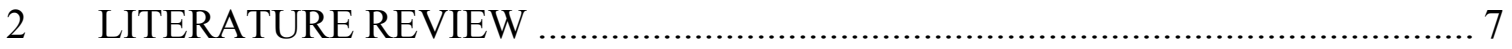

2.1 Historical Background of Rainwater Harvesting .................................................. 7

2.2 Rainwater Harvesting Technical Overview ..................................................... 8

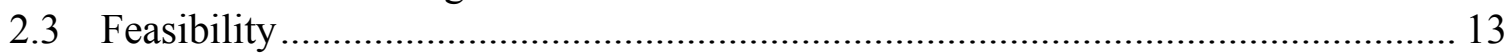

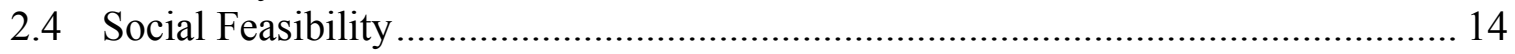

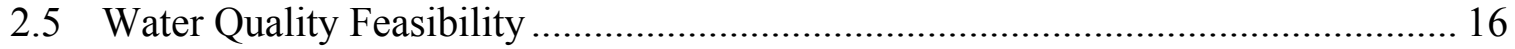

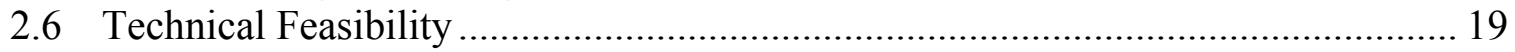

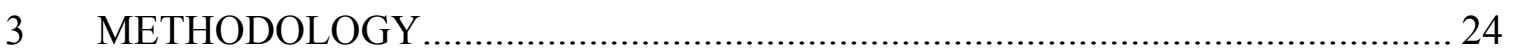

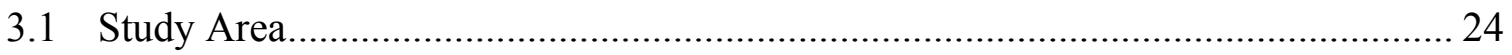

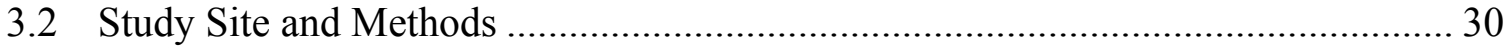

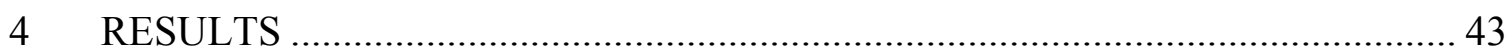

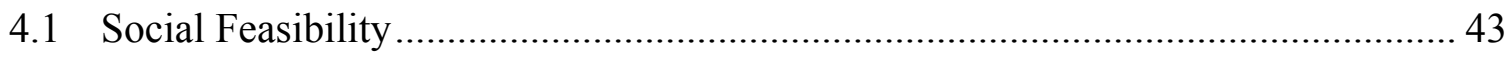

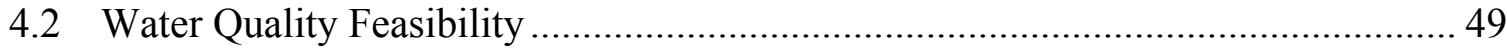

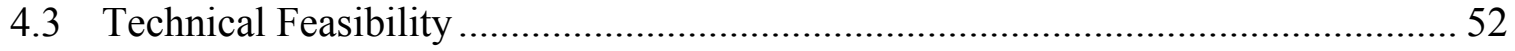

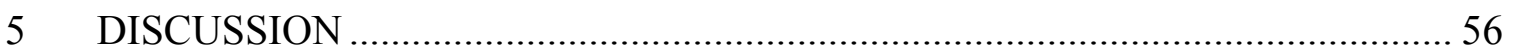

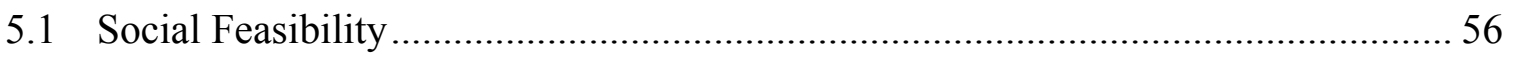

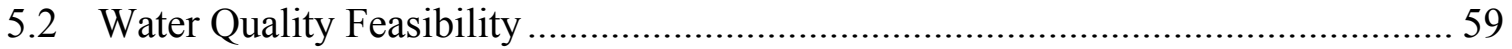

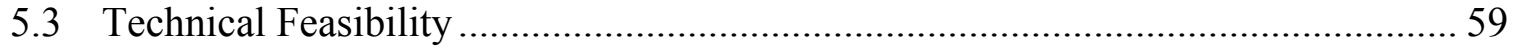

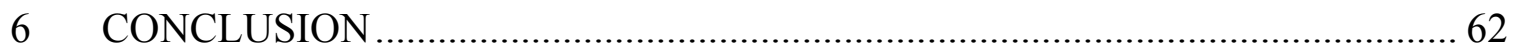

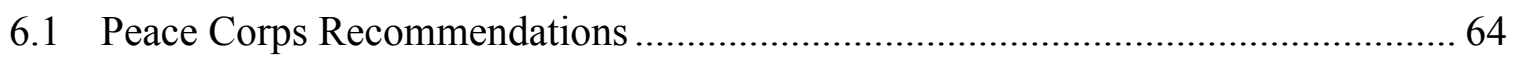

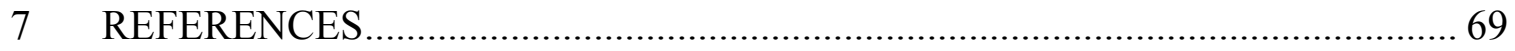

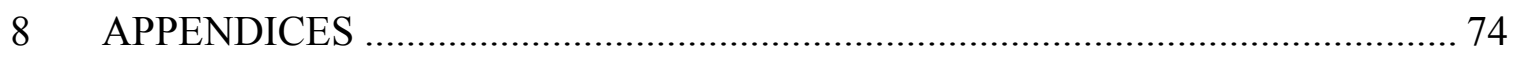




\section{LIST OF TABLES}

TABLE

PAGE

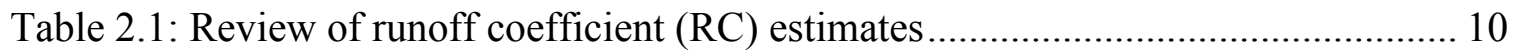

Table 2.2: Models for analyzing RWH performance................................................ 20

Table 3.1: 2010 Water withdrawal use and source (billions of cubic kilometers, $\mathrm{km}^{3}$ )... 25

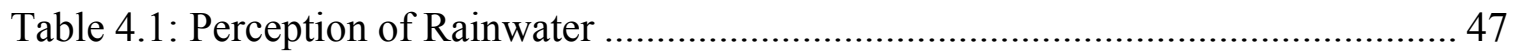

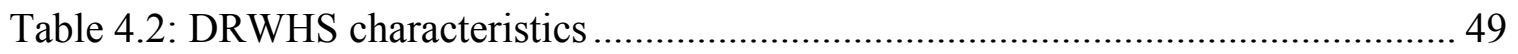

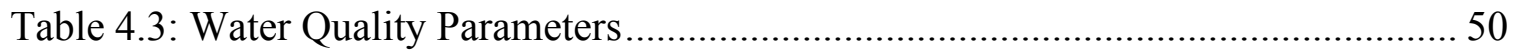




\section{LIST OF FIGURES}

FIGURE

PAGE

Figure 2.1: Typical DRWHS schematic ............................................................... 9

Figure 2.2: Commonly used storage tanks for domestic use. ................................... 12

Figure 2.3: Social, water quality, and technical feasibility factors to determine DRWHS sustainability, where some are interrelated. ......................................................... 14

Figure 3.1: Mexico's states Resiliency of Climate Change .......................................... 29

Figure 3.2: San Jose Xacxamayo located in Puebla, Mexico ....................................... 31

Figure 3.3: Current water challenges of daily commute to obtain water from well, for

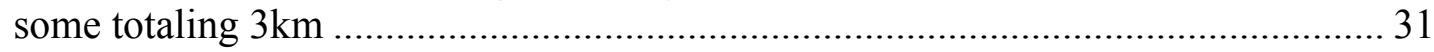

Figure 3.4: Chorro, the furthest water source available ......................................... 32

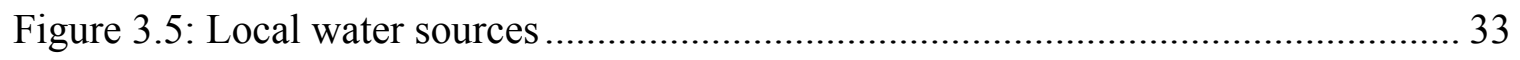

Figure 3.6: Monthly mean precipitation (1951-2010) from meteorological station

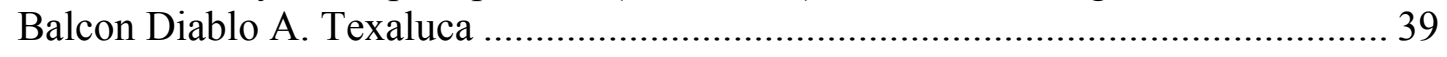

Figure 4.1: Household monthly income (USD) of participants................................... 44

Figure 4.2: Bathroom types of household surveys respondents. .................................. 44

Figure 4.3: Percent of users who use and collect local water sources by foot for

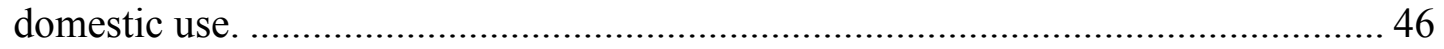

Figure 4.4: Frequency of days and months spent for water source collection................. 46

Figure 4.5: Collection time spent for local water sources. ...................................... 46

Figure 4.6: Burden of collection for local water sources where other accounts for people outside the household.............................................46

Figure 4.7: Mean annual precipitation variability under climatic scenarios

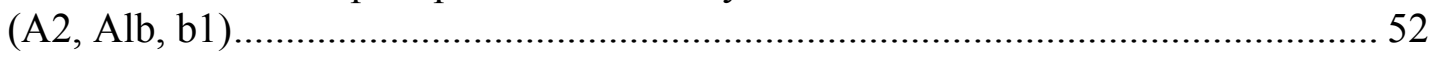

Figure 4.8: Monthly average precipitation for current and future climatic scenarios $(\mathrm{A} 2, \mathrm{~A} 1 \mathrm{~b}, \mathrm{~b} 1)$ 
Figure 4.9: Average domestic water consumption (liters) in San Jose Xacxamayo......... 54

Figure 4.10: Mid-Century (2046-2056) reliability of DRWHS under current and future

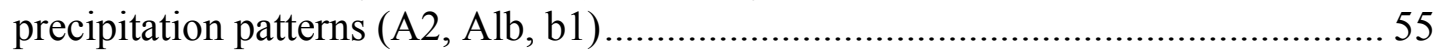

Figure 4.11: End of Century (2081-2100) reliability of DRWHS under current and

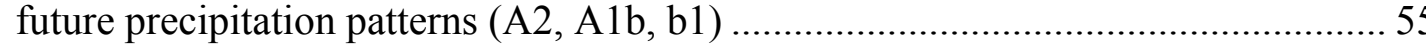




\section{INTRODUCTION}

\subsection{Peace Corps and Project Overview}

I served as a Peace Corps Volunteer in Mexico as a natural resource management specialist from August 2012-October 2014 in fulfillment of my Master International of Science at Florida International University. The Peace Corps was established in 1961 and currently volunteers are serving in 64 countries. Mexico is one of the more recent countries to collaborate with Peace Corps, having been established in 2004, and volunteers are assigned to work in one of the following sectors: technology transfer, environmental education, and natural resource management. I was assigned to work in Puebla, Mexico's $4^{\text {th }}$ largest city with 1.5 million inhabitants, working with Puebla's Ministry of the Environment, Secretaria de Medio Ambiente y Servicios Publicos (SMASP).

My primary role as a Peace Corps Volunteer consisted of aiding in the execution of adaptation measures from Puebla's municipal climate change plan (PACMUN) that SMASP passed in January 2013. The PACMUN was established with the aid of the International Council for Local Environment Initiatives (ICLEI), the technical support of National Institute of Ecology and Climate Change (INECC), and financed by the British Embassy in Mexico. The goal of PACMUN is to reduce Greenhouse Gas Emissions by $2 \%\left(65,749 \mathrm{tCO}^{2} \mathrm{eq} /\right.$ year $)$ in a 5-year period by applying 30 mitigation and 24 adaptation measures that were developed as a result of the their vulnerability assessment.

Within the PACMUN framework, I focused primarily on implementing rainwater harvesting systems for domestic use (DRWHS) and environmental education in San Jose Xacxamayo, a small rural community located in the southeastern part of the municipality 
of Puebla. The community of San Jose Xacxamayo has limited access to potable water, and relies on sources such as distant wells, the local river, and purchasing outside trucked water for their domestic water use. The community lacked sufficient resources, training, and government aid to manage and meet their water needs at a community level. Thus, household DRWHS is an approach they have adopted and utilized to manage their hydrological resources during the six-month rainy season and for part of their dry season. The DRWHS has reportedly saved them time and money compared to the other available water resources. However, there are some households that are still without a DRWHS or whose storage tank or roof size is inadequate to sustain their domestic water needs throughout the dry season.

Through an informal community assessment I conducted in March 2013, the community members reported that the expansion of DRWHS would address the water challenges they are facing, particularly those related to limited access to water for domestic uses. With collaboration from SMASP, I was able to secure funding from local and international organizations for the implementation of 82 DRWHS of 10,000-liter capacity and for 70 ceramic filters with silver colloidal lining from Centers for Appropriate Technology and Indigenous Sustainability (CATIS)-Mexico, which were used to treat the stored rainwater to make it suitable for consumption. My specific functions in the project were to facilitate resources, manage projects, and monitor and evaluate the implementation and use of the DRWHS and filters.

These DRWHS projects focused on community participation in the design, implementation, and maintenance stages, for example assuring that each household dug their own holes of approximately $2.75 \times 2.75 \times 1.9$ meters. Subsequently, local skilled 
workers constructed cisterns with the assistance of the beneficiaries and local students. In addition, I organized materials, capacity building events, and facilitators for the community members on the following topics: 1) Climate Change Impacts on Water Resources 2) Construction and Maintenance of DRWHS 3) Filter Usage and Maintenance and 4) Understanding Water Resources and Health.

The focus of this thesis was to assess whether rainwater harvesting could be a year-round sustainable solution for domestic use in rural, semi-arid communities in Mexico, such as San Jose Xacxamayo. The recipients of the DRWHS were the same households and community members that participated in this research.

\subsection{Water Security Challenges}

Although water is a basic human right and necessity, not all people have access to a clean, sufficient, and constant supply. In the developing world, many rural communities are located in water scarce areas where there is uneven distribution of hydrological resources and economic and/or political barriers to pipe and distribute water from the ground or surface (UN, 2007). Currently, approximately one-fifth of the global population faces water stress in which countries exceed water withdrawals by more than $20 \%$ of their available water resources (Arnell, 2004; UN, 2007). Climate change effects and a growing global human population, expected to reach 8 billion by the year 2025 , only exacerbate the pressure on water resource supplies (Imteaz et al., 2012; Alcamo et al., 2000). These stressors can impact the hydrological balance, disrupting historical patterns and causing phenomena such as: heavy precipitation events, droughts, and increases in tropical cyclone intensity (Bates et al., 2008). The domestic water sector in developing countries will be greatly affected by the aforementioned phenomena, with 
most areas facing an increasing demand for water with a diminishing water supply in the future.

Currently, the global domestic water supply is met principally by water from aquifers (groundwater) and rivers (surface water) (UN, 2007). The water quality of these resources globally has been deteriorating and the water supply diminishing due to population growth, pollution from expanding economic activities and climate change, among other factors. Rural and semi-arid areas are more vulnerable to the challenges of access to water. As a global average, only $81 \%$ of the rural population has access to an improved water supply source as opposed to the $96 \%$ of the urban population (WHO, 2012). As a result, there is a need for alternative water supplies in order to enable development without compromising human health or further damaging water resources.

Worldwide, the rural human population is the most vulnerable to water scarcity because of higher poverty rates and long distances to services, and thus rural populations are in need of improved access to water for domestic use and appropriate sanitation technologies (Crow, 2001; Barron, 2009). A reliable water supply is crucial for rural populations to be productive, especially since most rely on economic services (water supply, agriculture, fisheries, forest, livestock management) for their livelihood and economic development (Barron, 2009). Populations in semi-arid and arid rural areas are even more prone to water scarcity as compared to urban areas, as a result of little rainfall input and technological barriers.

Most urban water supply systems compromise a centralized network where governing agencies collect, treat, and distribute water. Often, rural communities do not have access to this network. This is a result of their remote location, lack of technical 
knowledge or skills, and resource constraints to maintain or operate such a system, leaving semi-arid, rural populations to rely individually on surface or groundwater sources (Peter-Varbanets et al., 2009). These available water sources in rural areas tend to be inconveniently located, financially costly, and face political obstacles (PeterVarbanets et al., 2009).

\subsection{Rainwater Harvesting}

Rainwater harvesting (RWH) is an ancient technology that is being revived and adopted in several countries such as Australia, China, Brazil, India, and Mexico as a sustainable approach to meet their water demands (Meera \& Ahmmed, 2006). Rainwater harvesting refers to the collection, storage and use of rainwater for domestic or agricultural purposes. Rainwater harvesting has been identified in many areas as an economically feasible solution to reduce strain on current water supply systems and provide optimal water quality. In addition, it is seen as an adaptive measure to address climate change effects on precipitation variability (Ndiritu et al., 2011). Rainwater harvesting has been an appealing alternative for rural populations, especially where a centralized water supply system is not viable (Barron, 2009). There have been numerous RWH studies that demonstrate the effectiveness to reduce users' vulnerabilities to water scarcity and improve their livelihoods (Barron, 2009; Mutekwa \& Kusangaya, 2007).

\subsection{Statement of Research}

The purpose of this research was to examine the feasibility of rooftop rainwater harvesting as a sustainable solution to current and future domestic household water demands in rural, semi-arid areas, through a case study of existing DRWHS in San Jose Xacxamayo, Mexico. This thesis defines sustainability under three specific criteria: 
DRWHS social acceptability and durability factors, rainwater quality (as fit for human consumption), and technical capacity of DRWHS to meet current and future demands with rainfall variability under different climate change emission scenarios (A1b, A2, b1).

\section{Specific objectives included:}

1- Evaluation of the social acceptability and durability factors of RWHS.

2- Examination of the quality of rainwater captured and stored for domestic use.

3- Application of a sensitivity assessment of current and future precipitation variability to the household domestic water demands and their current rainwater harvesting capacity and domestic water demands.

\section{Thesis Outline}

The scope of this paper examines rooftop rainwater harvesting at the household level for domestic use. The present literature review in Chapter 2 discusses historical and present use and design of DRWHS and rural populations need for water provisions. Following is an in depth examination of the sustainability of RWH through an assessment of the social, water quality, and technical feasibilities. The results and discussion in Chapter 4 and Chapter 5 explore the feasibility of DRWHS to supply clean and sufficient water in a rural, semi-arid community of Mexico. Chapter 6 presents the conclusion of the research and applies some of the lessons learned from my Peace Corps service as it relates to the findings. In addition, recommendations are provided for future Master

International students who conduct their thesis overseas during their Peace Corps volunteer service. 


\section{LITERATURE REVIEW}

\subsection{Historical Background of Rainwater Harvesting}

Rainwater harvesting systems (RWHS) are a technology used to collect and store precipitation from a catchment area and have been used by various cultures for several thousand years (approximately since 2000 BC). Rainwater harvesting systems are presumed to have originated in the Middle East and Asia and were used for agricultural and domestic needs; in many regions this was their primary source of water (Gould \& Nissen-Peterson, 1999). Among those countries that have a long history (over 2,000 years) of collecting rainwater to meet their water demands are: India, Japan, China, Turkey, Mexico and Thailand (Gould \& Nissen-Peterson, 1999; Meera \& Ahmmed, 2006). Mexico's use of RWHS dates back to 300 AD in the Yucatan Peninsula when RWHS was utilized through ground storage catchments by the Mayans (Gould \& NissenPeterson, 1999). Australia, New Zealand, Brazil, and the United States have also utilized RWHS, but comparatively on a more recent timescale. One such example of a more recent use of RWHS is seen in Australia since 1929, utilizing an ironclad catchment that fed into concrete tanks supplying water to a few people but mostly to livestock (Gould \& Nissen-Peterson, 1999).

Rainwater harvesting systems have the potential to provide reliable and durable infrastructure. Past use technologies implemented ranged from ceramic pots to concrete underground tanks. Several worldwide ancient examples that are still currently in good condition demonstrate the longevity of the different water storage technologies. One such example is a large cistern dating back to $532 \mathrm{AD}$ located in Istanbul, Turkey. The 
underground tank has a capacity of $80,000 \mathrm{~m}^{3}$ and is still standing, now as a popular tourist attraction (Mays et al., 2013).

Historically, RWHS allowed settlement and irrigation for particular areas such as islands, as seen throughout Japan and the Caribbean, and various dry regions. In dry areas, the amount of rainfall that utilized RWHS varied, with some areas having as little as $100 \mathrm{~mm} /$ year mean annual rainfall (Gould \& Nissen-Peterson, 1999). Israel and Australia were amongst the more arid locations that have utilized rainwater collection systems with low mean annual rainfall ranging from 100-300 mm/year (Gould \& NissenPeterson, 1999).

Despite the historical use of RWHS, population growth and urbanization have increased at an exponential rate resulting in a shift in the water supply and distribution technologies and creating a higher dependency on centralized systems. The utilization of RWHS is a decentralized approach to water supply and only until recently, with the mentioned pervasive water scarcity issues, is it being acknowledged as a contemporary, sustainable solution to meet water demands (Gould \& Nissen-Peterson, 1999; Mun \& Han, 2012). In today's world, many dry, poor and rural regions are utilizing this ancient technology to obtain domestic and agricultural water supplies for both present and future climatic conditions.

\subsection{Rainwater Harvesting Technical Overview}

Rainwater harvesting has two principal applications, agriculture and domestic use, and both can be applied to a centralized or decentralized system (DTU, 2002). A centralized system collects water in one reservoir from one or multiple catchments and is distributed to multiple users. A centralized system requires a large catchment area, 
storage tank, and in some cases a treatment system; requiring the coordination, operation, and management on a community level (DTU, 2002). A decentralized system consists of an individual catchment and storage area that is used at the household level. These systems are more commonly used for domestic rural water supply systems because they are cost effective and reliable (DTU, 2002).

Although there are varying technologies of DRWHS, they all serve to collect and store rainwater runoff for current and future use. DRWHS are composed of four essential components as shown in Figure 2.1: a catchment surface, conveyance system, storage tank, and delivery mechanism (Gould \& Nissen-Peterson, 1999). Following is a brief description of the four basic components.

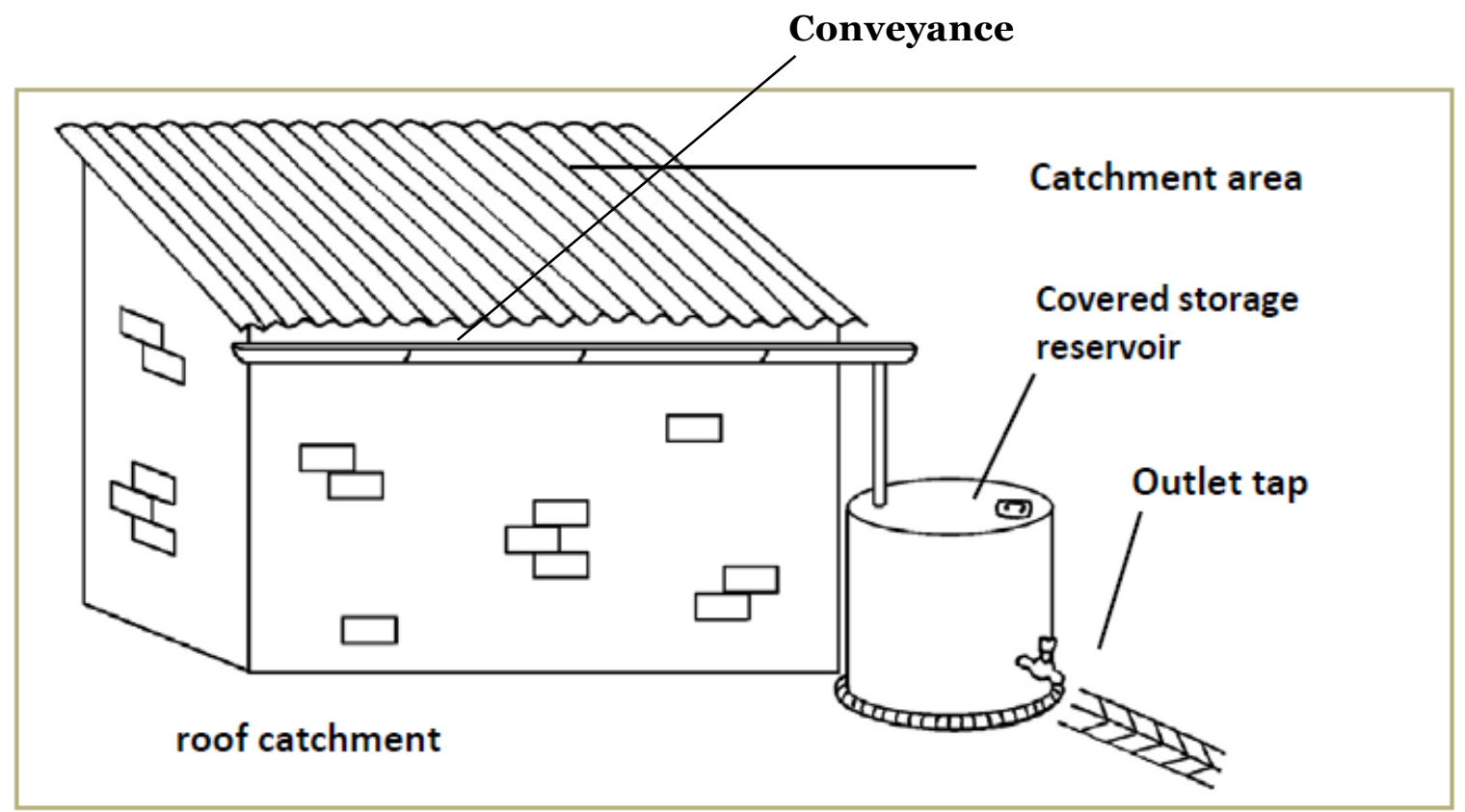

Figure 2.1: Typical DRWHS schematic (Source: adapted UNEP/IETC, 1998)

\section{Catchment Surface}

The catchment surface can affect the rainwater quality and is the primary factor in the quantity of water that can be captured (Gould \& Nissen- Peterson, 1999; DTU, 2002). 
The catchment surface is defined as the area where rain falls and is collected, which is typically a household roof surface. Metal, concrete, and iron sheets are a few of the common materials of surface catchments utilized for domestic use. The selected material for RWH should not affect the physical, chemical, or bacteriological content of the rainwater (Ludwig, 2005). The potential quantity of rainwater captured takes into consideration roof size, rainfall amount, and the runoff coefficient. The runoff coefficient (RC) determines the loss of rainfall conveyed to the tanks based on architectural factors (slope, imperviousness and infiltration efficiency of the surface materials) and climatic factors (moisture, wind occurrence, rain event size and intensity (Ferreny et al., 2011). Runoff yields are greater with impermeable surface material (DTU, 2002). Table 2.1 highlights the different surface material and their associated $\mathrm{RC}$ based on a review from Ferreny et al. (2011), where RC is estimated to lie within the range of .7-.95.

Table 2.1: Review of runoff coefficient (RC) estimates. Source: Ferreny et al., 2011

\begin{tabular}{lll} 
Roof & \multicolumn{1}{c}{ RC } & \multicolumn{1}{c}{ Reference } \\
\hline Roofs (in & $0.7-0.9$ & Pacey and Cullis (1989) \\
general) & $0.75-0.95$ & ASCE (1969), McCuen (2004), Singh (1992), \\
& & TxDOT (2009), Viessman and Lewis (2003) \\
& 0.85 & McCuen (2004), Rahman et al. (2010) \\
& $0.8-0.9$ & Fewkes (2000) \\
& 0.8 & Ghisi et al. (2009) \\
& $0.8-0.95$ & Lancaster (2006) \\
Sloping roofs & \\
Concrete/ & 0.9 & Lancaster (2006) \\
asphalt & & \\
Metal & 0.95 & Lancaster (2006) \\
Aluminium & $0.81-0.84$ & Liaw and Tsai (2004)) \\
Flat roofs & & Ward et al. (2010) \\
Bituminous & 0.7 & Ward et al. (2010) \\
$\begin{array}{c}\text { Gravel } \\
\text { Level }\end{array}$ & $0.8-0.85$ & Lancaster (2006) \\
cement & 0.81 & Liaw and Tsai (2004)) \\
\hline
\end{tabular}




\section{Conveyance System}

A conveyance system functions to transport collected runoff from the catchment surface to a storage reservoir through a combination of gutters and downspouts. Gutters surround the parameter of the roof and vary in types and sizes from PVC pipe, aluminum, or galvanized steel (Ludwig, 2005). Mesh screens are usually applied to the top end of the gutters to prevent leaves and debris from reaching the storage tank (Thomas \& Martinson, 2007; Veenhuizen \& Prieto-Celi, 2000).

\section{Storage Tank}

The storage tank is an important component to adequately hold the rainwater input needed for the household demand year-round. The location of storage tanks can be constructed either aboveground or underground. The location is best tailored to meet the specific needs of the household with climate and topographic considerations (Thomas \& Martinson, 2007). Aboveground storage tanks are easier to inspect and maintain, and delivery can be by gravity extraction. However, some drawbacks include exposure to weather, required space, and increased susceptibility to damage. Underground tanks can be advantageous because of structural ground support, reduced stored water temperature, and preservation of space, whereas disadvantages include manual extraction, tank leaks being difficult to detect, and risks of pollution entering from ground contaminants (Gould \& Nissen, 1999; Thomas \& Martinson, 2007).

Determinants of the tank size are the quantity and seasonality of precipitation, household water demand, catchment surface area, economic feasibility, personal preference, and local skills and knowledge (TWDB, 2005). Numerous DRWH tank designs and sizes exists worldwide, with the most represented types being plastics, 
fiberglass, polypropylene, PVC, metals (galvanized steel), wood, or concrete (Ludwig, 2005). A few of these types (concrete, ferrocement, plastic) are depicted in Figure 2.2, and as utilized in this paper's case study site.

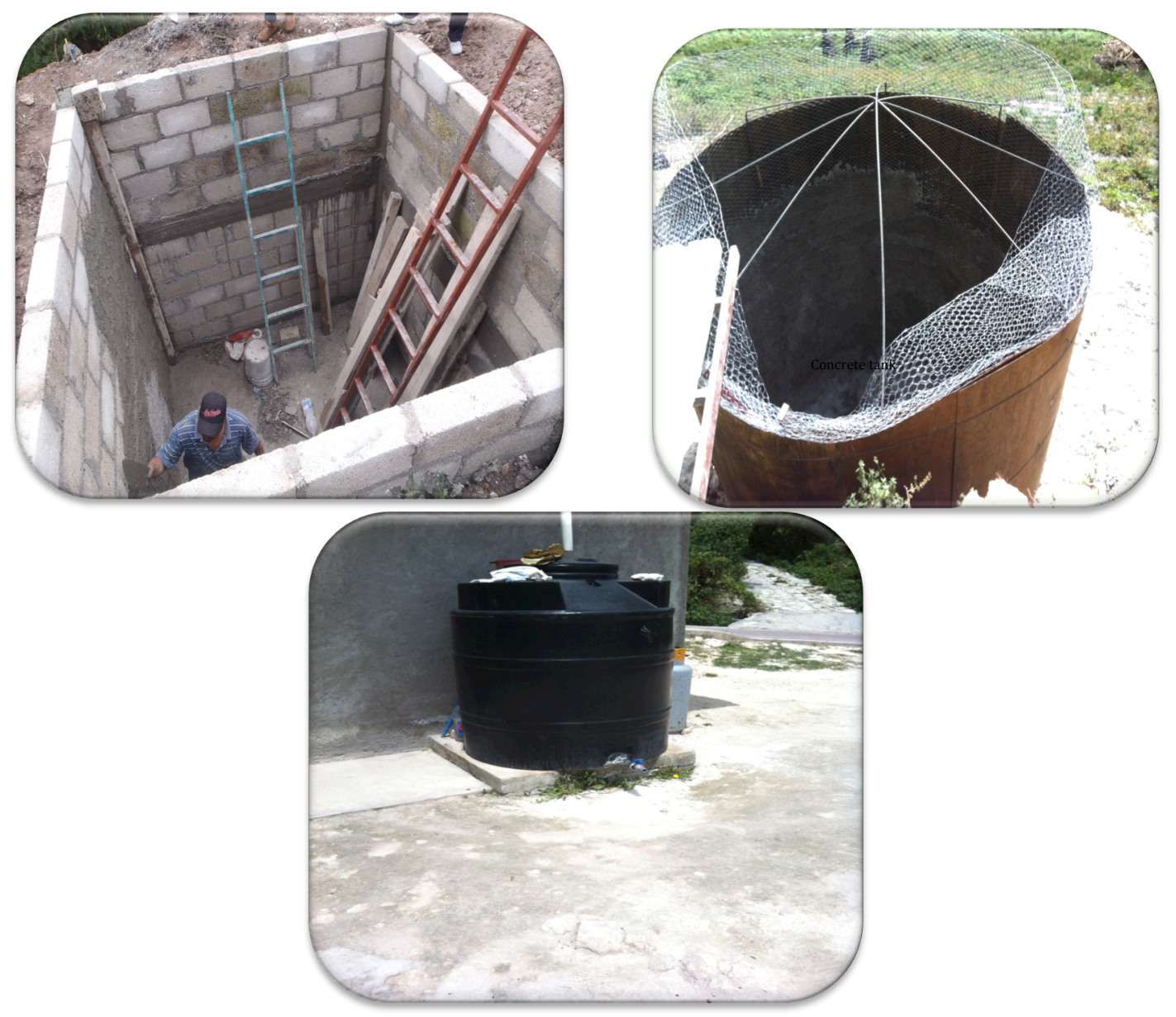

Figure 2.2: Commonly used storage tanks for domestic use. Top left: Concrete (in construction) Top Right: Ferrocement (in construction) Bottom Center: Rotoplas (Plastic:HDPE)

In addition, there are some other considerations that should be made with the DRWHS design for optimal function and durability, management ease, and improved water quality health. One such consideration for the DRWHS design includes a first flush device to divert first rains of the season; ensuring all surfaces are sealed properly to 
prevent cracks and entrance of contaminants is another consideration. The tank design, with the considerations mentioned, is of utmost importance to ensure longevity of the system. Ludwig (2005) gives a detailed comparison of most existing RWH systems for both agricultural and domestic use, with most systems lasting an average of $15+$ years.

\section{Delivery Mechanism}

The delivery mechanism is the device used for water extraction from the storage tank. The design will impact the delivery mechanism in whether it can be gravity driven (aboveground tanks) or will require a more labor-intensive manner of extracting the water from hand pump or buckets (underground tanks).

\subsection{Feasibility}

The sustainability of DRWHS depends on various factors, including social acceptability, water quality, and ability to meet household demands given spatial and temporal variability of rainfall. There are few studies that encompass all of the listed components. Therefore many case studies lack sufficient information to determine the viability of RWH for domestic water supply.

As mentioned previously, this research examines the sustainability of the DRWHS in semi-arid, rural regions in a community case study that explores the social, water quality, and technical feasibilities of the systems. This thesis was developed on the basis of literature reviews and through first hand experience with implementation of said systems through my Peace Corps service. Figure 2.3 shows the factors considered for this research and examines each one through prior studies. 

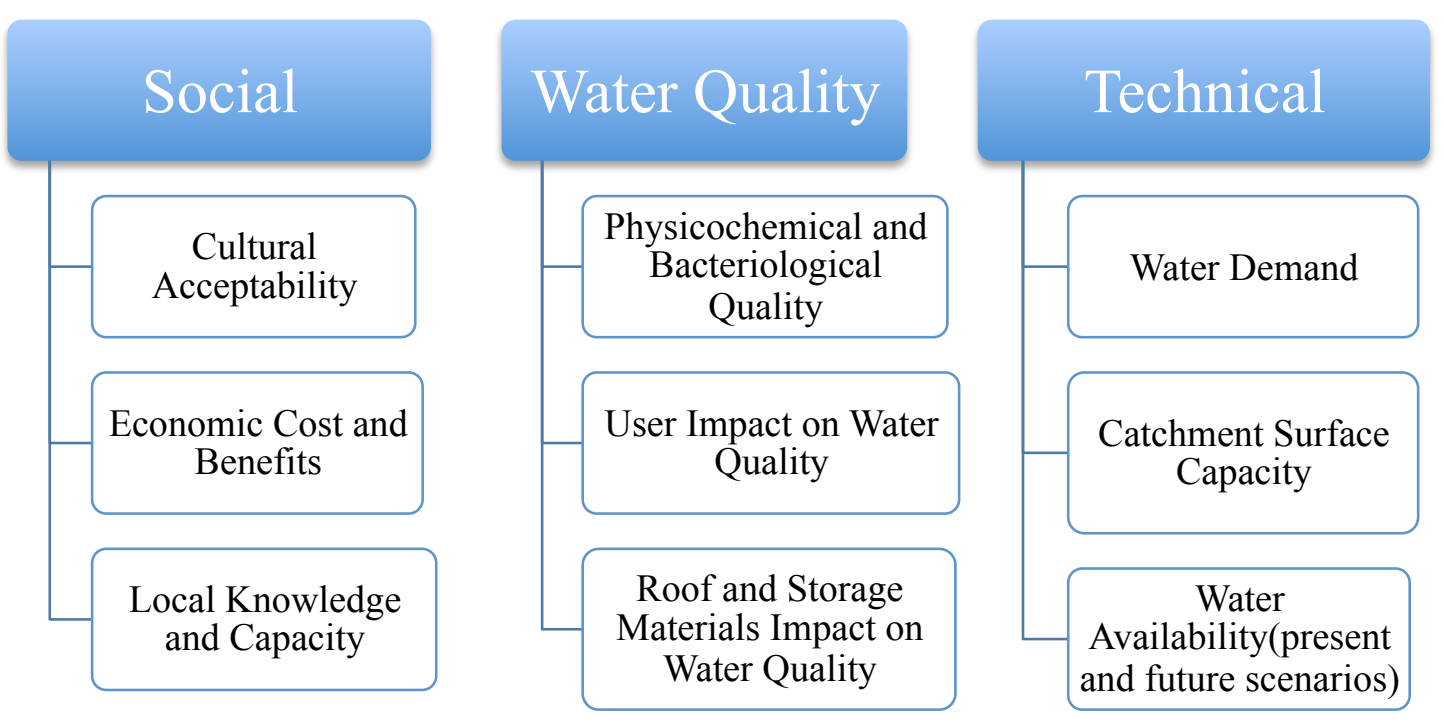

Figure 2.3: Social, water quality, and technical feasibility factors to determine DRWHS sustainability, where some are interrelated.

\subsection{Social Feasibility}

For successful DRWHS adoption in rural communities, it is critical to examine the social factors such as the social acceptability (beliefs and attitudes), economic benefits, and local knowledge and technical capacity. Although there may exist a need for an improved water provision, there may be several reasons for resistance to accept a RWH technology. For example, the technology may require skill levels beyond that of the community inhibiting their adoption for a complex system. In addition, the technology may not be the user's preference. For instance, some communities prefer underground to aboveground tanks because they take up little surface area, allowing the top of the tank to be used for other purposes (i.e. outside patio).

Gender roles and cultural perceptions and beliefs about the storage and use of rainwater can prevent successful implementation, making them important factors in the 
design and distribution of DRWHS. Quite frequently, social programs for DRWHS promote the implementation of the new technology without factoring in cultural components (UNEP, 1997). One study in rural Nepal from Bajracharya and Deverill (2001) concluded that for a community-based approach, the feasibility of a new technology is largely dependent upon compatibility with the local culture. For instance, women play a large role in the function of the systems since they largely rely on the DRWHS for cooking, cleaning, and other domestic uses, thus their inclusion in the technology and maintenance strategies is recommended in the system design and implementation (Hazards, 2011). Culture and beliefs can impact the use of rainwater for drinking and depends on the user's perception of taste, odor, and appearance (Sheat, 1992; Doria, 2010). The reliance on senses can lead to the continued use of other water sources that may be more contaminated, foregoing the opportunity to change behavior and opt for a more reasonable and improved supply option (WHO, 2003).

\subsubsection{Economic Benefits}

Much of the literature concludes that most DRWHS in rural areas are not economically feasible in comparison to a nearby centralized water supply system (Kim \& Yoo 2009; Islam et al., 2010; Gardner \& Vieritz, 2010). However, many of these studies account for available centralized systems and do not consider the social or physical factors (social dynamics, local government stability, current availability) that can affect whether an alternative supply would be more economically beneficial than a centralized system. One study that contradicts the prior findings is from Alam et al. (2012) who concluded that private and conventional supply systems are 3.5-4 times more costly than that of a RWHS. Economic feasibility of RWH use can be altered with the financial aid 
of local, federal, and international institutions. However, available financial aid is difficult to obtain because in most instances a solicitation is required from the community members, whom are unaware of such programs for financial support. Another important consideration is to utilize local materials to lower costs of the systems and to be able to maintain the systems in the future. In addition to associated upfront costs with adoption of RWH technologies, the long term economic benefit should be valued as well. Women and children tend to be impacted by water scarcity by requiring increased time investment to collect and manage water, which may hinder economic productivity, increase health issues and associated costs, and impede educational achievement.

Another major constraint to adopting DRWHS in rural areas is willingness to adopt and use the systems contingent on the user's knowledge and skill level to implement and maintain the technology alone. Hence it is crucial to involve the community in the planning, design, and implementation of the systems, without this participation system failure typically results (Hazards, 2011). In some cases in Mexico, institutions promote their own RWH technologies without community input or transfer of the technology that can affect the long-term costs and durability of the system. For example insufficient capacity of the user to repair their system may require a higher investment to transport material or technical aid.

\subsection{Water Quality Feasibility}

Currently it is estimated that 2.2 million deaths a year are a result of waterborne diseases such as diarrhea (WHO, 2010; Olaoye \& Olaniyan, 2012). In the absence of a safe drinking water, rural communities rely on sources that are highly contaminated or where contamination levels are unknown. Ensuring proper water quality is maintained is 
key for disease prevention and management of waterborne diseases (Olaoye \& Olaniyan, 2012).

The quality of rainwater is an important determinant for opting to utilize a DRWHS for potable uses. Several studies have demonstrated that rainwater is considered to be high quality, free of contamination before interacting with the atmosphere or storage tank (Helmreich \& Horn, 2009; Schets et al., 2010, WHO 2008, Choudhury \& Vasudevan, 2003). However, there is limitation of DRHWS applied for potable uses because few studies demonstrate that water meets potable guidelines and most studies that are carried out are from experimental designs instead of existing systems. In addition, there are high uncertainties that the user can properly manage and maintain the system to ensure optimal water health (Domènech, et al., 2012). The available literature varies in results of rainwater quality; most studies examine three main characteristics to determine suitability of water quality: physicochemical properties, microbiological properties, and heavy metal concentration.

Many studies of rooftop collection systems have documented rainwater quality that meets the physicochemical WHO standards, with the exception of $\mathrm{pH}$ (Pushpangadan et al., 2001; Chang et al., 2004). Other studies report microbial contaminants and heavy metal levels that exceed drinking water international guidelines (Abbott et al., 2006; Vasudevan \& Pathak, 2000). However, direct rainwater quality comparisons are difficult to establish because of varying analytical methods as well as regional variations (topography, pollution source proximity, DRWHS design and management) of the sampled locations (Sazakli et al., 2007; Zhu et al., 2004; Gould, 1999; Mwenge Kahinda 
et al., 2007). However, much of the literature concludes that rainwater is unfit for direct human consumption without additional treatment (Schets et al., 2010).

Rainwater quality that is captured and stored for domestic use varies by three primary factors: rainfall intensity, atmospheric pollution, and collection systems. The rainfall intensity is an uncontrollable factor that can affect the water quality that is captured and stored. Both the rainfall intensity and the dry days prior to rain events can affect the rainfall quality (Abdulla \& Al-Shareef, 2009). Rainwater, prior to contacting a surface, can be contaminated through atmospheric pollution from dissolved gases as a result of industrial activity. Highly urbanized areas tend to have increased atmospheric pollutants because of high population and industrial activity, causing localized contaminated rainwater whereas rural areas, which tend to be further from industrial pollution, may be a more suitable location to implement DRWHS (Helmreich \& Horn, 2009; Heijnen \& Pathak, 2006).

The design of a proper rainwater collection system is essential to minimize and prevent rainwater quality deterioration. Research has shown there are two principal areas of concern in relation to rainwater contamination within the collection system: the catchment surface and the storage tank. The catchment surface is where contamination occurs more frequently (Gould \& Nissen, 1999).

Bird and animal feces can be one contributor to rain contamination on catchment surfaces. Feces pose hazards because they can increase the bacteriological contamination in the rainwater, a water quality indicator. Coliform bacteria, a microbial indicator, has been analyzed through various rainwater quality studies showing counts up to thousands CFU/100 mL, meaning the water is highly contaminated (Helmreich \& Horn, 2009). 
One of the concerns that can arise is the quality of the rainwater diminishing because of contact from the roof material, which in several studies has shown that heavy metals are leached into the water. Heavy metal contamination in rooftop-harvested rainwater has been found with metal roofs in the form of zinc, copper, lead and cadmium. Other roof types that contributed to lead contamination were found in galvanized iron roof (Simmons et al., 2001) and asphalt shingle roof (Metre \& Mahler, 2003). Much of the literature recommends avoiding materials such as zinc, copper, and metallic paint roofs to prevent heavy metal contamination (Helmreich \& Horn, 2009). Tile, aluminum sheets, and slates have been shown to be associated with lower levels of stored rainwater contamination (Helmreich \& Horn, 2009; Gould, 1992).

\subsection{Technical Feasibility}

One of the issues of RWHS is failure to establish the system feasibility prior to implementation and hence reliability of the technology can be compromised. Several studies worldwide have examined DRWHS feasibility through optimization methods on design and capacity to meet household water demands and are categorized as: graphical and mass curves, statistical, and behavioral (simulation) methods (Bailey \& Wallace, 2015; Jenkins et al., 1978; Youn et al., 2012). A study from Ward et al. (2010) summarizes the several approaches that exist to size a rainwater tank that is sufficient for the user demand (Table 2.2). 
Table 2.2: Models for analyzing RWH performance (Source: Ward et al. 2010)

\begin{tabular}{|c|c|c|c|}
\hline Model & Developer & RWH only? & Functionality \\
\hline DRHM & Dixon (1999) & Yes & $\begin{array}{l}\text { Mass balance with stochastic elements for demand } \\
\text { profiling, simulates quantity, quality and costs }\end{array}$ \\
\hline Rewaput & $\begin{array}{l}\text { Vaes and Berlamont } \\
\text { (2001) }\end{array}$ & Yes & $\begin{array}{l}\text { Reservoir model, rainfall intensity-duration-frequency } \\
\text { relationships and triangular distribution }\end{array}$ \\
\hline $\begin{array}{l}\text { RWIN } \\
\text { (KOSIM) }\end{array}$ & $\begin{array}{l}\text { Herrmann and Schmida } \\
\text { (1999); ITWH (2007) }\end{array}$ & No & $\begin{array}{l}\text { Hydrological-based high resolution ( } 5 \text { minute) rainfall- } \\
\text { runoff model }\end{array}$ \\
\hline PURRS & $\begin{array}{l}\text { Coombes and Kuczera } \\
(2001)\end{array}$ & No & $\begin{array}{l}\text { Probabilistic behavioural, continuous simulation, } \\
\text { evaluates sources control strategies }\end{array}$ \\
\hline RCSM & Fewkes (2004) & Yes & $\begin{array}{l}\text { Behavioural, continuous simulation, detailed analysis of } \\
\text { time interval variation and yield-before/after-spill }\end{array}$ \\
\hline MUSIC & CRCCH (2005) & No & $\begin{array}{l}\text { Continuous simulation, modelling water quality \& } \\
\text { quantity in catchments }\left(0.01 \text { to } 100 \mathrm{~km}^{2}\right)\end{array}$ \\
\hline Aquacycle & Mitchell (2005) & No & $\begin{array}{l}\text { Continuous water balance simulation using a yield - } \\
\text { before-spill algorithm }\end{array}$ \\
\hline RSR & Kim and Han (2006) & Yes & $\begin{array}{l}\text { RWH tank sizing for stormwater retention to reduce } \\
\text { flooding, using Seoul as a case study }\end{array}$ \\
\hline RainCycle $\subset$ & $\begin{array}{l}\text { Roebuck and Ashley } \\
\text { (2006) }\end{array}$ & Yes & $\begin{array}{l}\text { Excel-based mass balance model using a yield-after-spill } \\
\text { algorithm and whole life costing approach }\end{array}$ \\
\hline HWCM & Liu et al (2006) & No & $\begin{array}{l}\text { Object-based behavioural ,continuous simulation using } \\
\text { Simulink }\end{array}$ \\
\hline
\end{tabular}

The complexity and purpose of each model can vary. Graphical and mass curve methods are typically applied as in the preliminary design of the tank and can be used for rapid assessment, however tank size is limited for a given supply. A statistical approach is used to determine the inflow and potential releases of a large storage tank (Liaw \& Tsai, 2004). The present paper applies the most frequently applied methodology, the behavioral method, as a result of the effective and economic applicability amongst stakeholders.

\subsubsection{Water Balance Simulation Model}

The behavioral method is derived from the water balance equation to calculate the volume yield of a tank in a given time, which is a function of rainfall, catchment size, runoff losses, tank size and user demand. The original concept was developed by Jenkins et al., (1978) and later adapted by Fewkes \& Butler (2000) by applying operational algorithms (yield before spillage and yield after spillage) to assess behavioral model 
accuracy in RWHS sizing. In addition, investigation by Fewkes (2000) applied and incorporated fluctuations in rainfalls spatial and temporal distribution into behavioral models (Ward et al., 2010). The behavioral method can provide accurate and continuous results for the RWHS input, output and volume in a defined period of time (Fewkes \& Butler, 2000; Liaw \& Tsai, 2004; Imteaz et al., 2012).

\subsubsection{Reliability}

The reliability of RWHS is an important parameter to determine the rainwater supply delivered by the tank in meeting the users demand over a given time according to the applied simulation method (Imteaz et al., 2012). Reliability determines the frequency that the demand is met and can be determined on a volume or time-based scale. Volumebased reliability considers the total volume of supplied rainwater in the tank divided by the total demand of water within the simulation period. Whereas time-based reliability, a more conservative approach, determines the amount of time that the total water demand is met by the tank supply (Liaw et al., 2004; Palla et al., 2011).

Future water resource availability is dependent upon climate change, which is affected by an increasing concentration of GHGs in the atmosphere. The expected changes with the hydrologic pattern will impact the distribution and percentage of the world's population that will be affected by water stress (Arnell, 2004). It is estimated that by 2025 , two-thirds of the global population will be living in water stress countries (Arnell, 2004). Domestic rainwater harvesting systems efficiency is affected by the precipitation fluctuations in distribution patterns making it critical to estimate for current and future supply of DRWHS under precipitation vulnerabilities to ensure it can meet the demands year-round. 
Future projections of GHG emission scenarios were published in the Intergovernmental Plan on Climate Change (IPCC) Special Report on Emissions Scenarios (SRES) in 2000 (IPCC, 2000). Although there are great uncertainties with climate change projections, the scenarios depict different climate events using reasonable future assumptions, including economic and population growth. Water managers and planners should account for the uncertainties in order to plan strategically for the future. By incorporating analyses of the different climatic scenarios, the future water availability can be estimated which allow for the determination of the reliability of DRWHS under the assumptions.

Different scenarios take into consideration various factors in the projections: population, economies, political structure and lifestyles. The scenarios are grouped into four families (A1, A2, B1, B2) of which three specific scenarios (A1, B1, A1b) will be examined in this research. The A2 is projected to have a high population growth and A1 and $\mathrm{B} 1$ scenarios have equally low population growth. In addition, under the A1 and B1 scenarios, energy sources are considered balanced, where B1 presents increased advancement of energy efficient technologies (Arnell, 2004). The A1 and B1 scenarios predict that in 2055 that number of affected people in water stress areas will be 3.4 billion (Arnell, 2004). The A2 scenario predicts that the number of affected people in water stress areas will reach 5.6 billion people for that same year (Arnell, 2004).

In summary, the present literature review discussed the challenges facing rural communities in semi-arid areas and used past studies of the adoption of DRWHS to examine the sustainability in terms of the social, water quality, and technical feasibility. The present literature remains inconclusive due to regional variation of the feasibility 
assessment, which cannot be applied to all rural populations. For instance, although heavy metals were found in some of the studies, this was largely a result of the type of roof and tank material, and which material types were studied was limited. In addition, many studies were carried out in a controlled environment, lacking extensive research of existing DRWHS. The present case study examines the sustainability of existing DRWHS implemented as a part of my Peace Corps service and aims to shed light on some additional factors that can be considered in the specific case in a rural area of Puebla, Mexico to make the adoption of DRWHS more successful and sustainable. 


\section{METHODOLOGY}

\subsection{Study Area}

Mexico, as of 2010, has a population of approximately 112 million people, of which an estimated 11 million live without reliable access to safe drinking water and over 13 million people have no access to proper sanitation facilities (CONAGUA, 2013; INEGI, 2010). Current and future water challenges pose severe social and economic consequences to Mexico, a country with a unique and diverse economy, ecology, and culture. Rural residents account for $23 \%$ of Mexico's total population and are the most afflicted by water quantity and quality issues because of poverty and lack of infrastructure and economic opportunities. As of 2010, 25\% of Mexico's rural population lives without access to a safe water supply whereas $6 \%$ of the urban population lacked these services. Nearly $35 \%$ of the rural population lacked sanitation services compared to $5.5 \%$ of the urban population (CONAGUA, 2013).

Mexico is composed of 31 states and a federal district and has a variety of climates as a result of the country's geography and relief; these climates directly impact water resource availability (CONAGUA, 2013). The climatic variety results in variable precipitation throughout Mexico, where there is heavy rainfall in the southern regions and dry climate with little rainfall in the central and northern regions. The southeast region is humid with precipitation averaging over 2,000 $\mathrm{mm} /$ year. However, most of the country $(2 / 3)$ is dry and classified as arid or semi-arid having an annual precipitation of less than $500 \mathrm{~mm}$ (CONAGUA, 2013). The majority of the rainfall in Mexico (77\%) occurs between the months of November to May. Of Mexico's total precipitation, approximately 
$25 \%$ discharges into rivers and lakes, $2 \%$ recharges the aquifers, and $73 \%$ evaporates directly or through evapotranspiration of plants (Rhonda \& Burton, 2010).

\section{Water Resources}

Mexico encounters water supply challenges because of low precipitation in the northern and central regions, where most of the population and economic growth occurs. As a result, these areas rely heavily on groundwater use, leading to increased vulnerability of aquifer depletion (Scott, 2011). The water withdrawal volume in Mexico, as illustrated in Table 3.1, totaled 82.7 billion $\mathrm{km}^{3}$ in 2010 of surface and groundwater and is allocated to agriculture, public water supply, industry, and hydroelectric power generation. The agriculture sector alone accounts for three-fourths of Mexico's total water withdrawals, accounting for $76.6 \%$, the public water supply sector uses $14.5 \%$, the industrial sector constitutes 4.0\%, and thermoelectric plants 4.9\% (CONAGUA, 2013). Of the $14.5 \%$ of the public water supply total withdrawal, Mexico relies more heavily on groundwater resources for public water supply $\left(7\right.$ billion $\left.\mathrm{km}^{3}\right)$ in comparison to surface waters $\left(4.2\right.$ billion $\mathrm{km}^{3}$ ). Given the population size, this implies that public water supply can allocate $100 \mathrm{~km}^{3}$ per capita which would be sufficient to meet the domestic water demands of the population. However, this is not the case.

Table 3.1: 2010 Water withdrawal use and source (billions of cubic kilometers, $\mathrm{km}^{3}$ ) (Source: CONAGUA, 2013)

\begin{tabular}{ccccc}
\multirow{2}{*}{ Use } & \multicolumn{2}{c}{ Source } & $\begin{array}{c}\text { Total } \\
\text { Volume }\end{array}$ & $\begin{array}{c}\text { Percentage of } \\
\text { Withdrawal }\end{array}$ \\
\hline Surface Water & Groundwater & & & \\
Agriculture & 41.2 & 22.2 & 63.3 & 76.6 \\
Public Water Supply & 4.7 & 7.3 & 12 & 14.5 \\
Self-Supplying Industry & 1.4 & 1.9 & 3.3 & 4.0 \\
Thermoelectric plants & 3.6 & 0.4 & 4.1 & 4.9 \\
Total & 51.0 & 31.8 & 82.7 & 100 \\
\hline
\end{tabular}


Less than half (29.5\%) of Mexico's water comes from their 653 aquifers, of which 106 are over-exploited, surpassing the extraction recharge rate by $9.5 \%$ (Rhoda \& Burton, 2010; Scott, 2011; CONAGUA, 2013). Although groundwater extractions are less than surface water, there has been a $2.5 \%$ annual increase of total groundwater use over the periods of 2001-2008, and groundwater withdrawal is continuing to increase. Overexploited aquifers in 2012 accounted for nearly $60 \%$ of the total groundwater extracted (Rhoda \& Burton, 2010). As a result, there is increasing water stress on the current water supply system.

According to FAO, water availability per capita in Mexico ranks $90^{\text {th }}$ out of 177 countries analyzed (Rhoda \& Burton, 2010). It is reported that the average Mexican uses 270 liters/capita/day (1/c/d) for domestic purposes (CONAGUA, 2013). Although this is a sufficient amount for survival and health not all the population's water demands are being met. For instance, Puebla, Mexico's $4^{\text {th }}$ most populous city, with 1.5 million people, provides water quantities below the recommended volume of 200 liters/capita/day, according to Consejo Consultivo del Agua (CCA), providing only 117 liters/capita/day, less than half of what the average Mexican uses.

In addition to inefficient quantity of water in Mexico, poor water quality is an issue as well, with contamination of both surface and groundwater posing health hazards to the Mexican population. It is estimated that over $90 \%$ of Mexico's surface water is contaminated primarily from untreated residential and industrial wastewater (Hearne, 2004). The primary contaminants entering Mexico's waterways as a result of these sources are fecal coliform, oil and grease, phosphates, dissolved solids, and detergents. As of 2010 less than half, $46.5 \%$, of Mexico's wastewater collected was treated, allowing 
for polluted water to enter their waterways (CONAGUA, 2012). In Puebla the amount of wastewater treated is less: only $35 \%$ of the used water is treated before being discharged into the local water sources (OECD, 2013). Although industries account for a small portion of water withdrawals, their water pollution discharge is three times more than household users. Industries discharge substances that can be highly toxic, such as mercury and arsenic, which have been reported in many of the aquifers in Mexico.

Because of groundwater over-extraction, contaminated surface water, and lack of wastewater treatment, Mexicans rely on bottled water for safe consumption, ranking them as the world's largest consumers of bottled water. According to Euromonitor International, in 2013 Mexico's average bottled water consumption was 186.7 liters/person, surpassing Italy by an order of magnitude of 11.6 liters/person (Rhoda \& Burton, 2010). The average 1-liter bottle costs around 8 pesos ( $\sim$ 1 USD) and a 20-liter costs between 15-20 pesos ( $\sim 1.5$ USD). Depending on the family size, the monthly costs incurred for bottled water consumption is considerable when $60 \%$ of the Mexican population's income was $\sim \$ 6,800 /$ person in 2005 (Rhoda \& Burton, 2010).

\section{Water Resource Management}

The ownership and management of surface and groundwater in Mexican territory was appointed to the federal government in Article 27 of the 1917 Constitution, and regulation is conducted through National Commission on Water (now CONAGUA) under the Ministry of Environment and Natural Resources (SEMARNAT). Water supply and sanitation (WSS) is delegated to municipalities under the constitution (Hearne, 2004). However, municipalities have had a high dependency on the central government for water provisions (Hearne, 2004). The 1992 National Water Law, amended in 1994, 
decentralized water management into municipal territories. In addition, the law allowed users the right to use resources through allocated 50-year concessions (Hearne, 2004). SEMARNAT is given authority under this law to establish guidelines and standard of water quality in collaboration with the Ministry of Health. The National Water Law authorizes CONAGUA as the responsible stakeholder to ensure water quality, In addition, industries are permitted to sample and analyze their own wastewater discharge. The decentralized water policy and multilayer stakeholders cause inadequate enforcement that creates increasing water supply challenges and poor water quality (Hearne, 2004; OECD, 2012).

\section{Climate Change Impacts on Water Resources}

In 2008, Mexico was ranked $13^{\text {th }}$ globally in GHG emissions emitted (excluding forestry, land use, and land use change). It is considered one of the most vulnerable countries to climate change impacts, causing high exposure to direct adverse effects to $15 \%$ of the territory, $68 \%$ of the population, and $71 \%$ of their GDP (OECD, 2013). The federal government and some state and municipal governments recognize the vulnerabilities and challenges they face with climate change and have enacted laws and measures to address and reduce impacts. Figure 3.1 depicts Mexican states' resiliency to climate change impacts per sector; water availability ranking amongst the least resilient in most states. Puebla is the $6^{\text {th }}$ least resilient to climate change where food security, health, human resources and economic capacity are the sectors that are most vulnerable. 


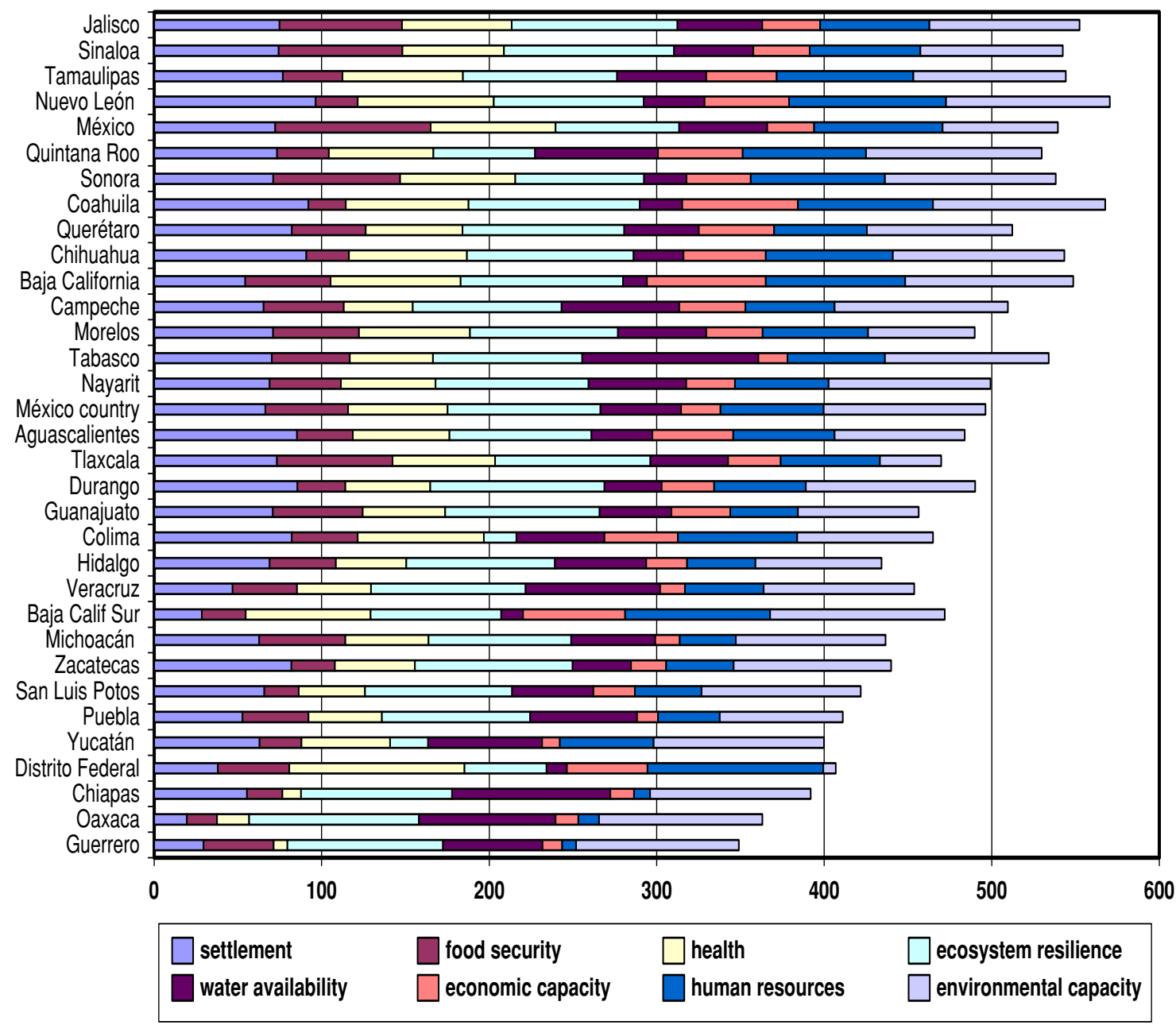

Figure 3.1: Mexico's states Resiliency of Climate Change (Source: Ibarrarán et al., 2010)

\section{Rainwater Harvesting}

Mexico is one of many countries that have implemented RWHS to address water supply challenges. There are no regulatory restrictions or guidelines for rainwater harvesting within Mexico. The insufficient federal guidance results in numerous institutions, both nationally and internationally, to offer technical and financial support to implementing RWHS (Meehan, 2010). Some of the challenges facing communities that do not have access to water and want to implement such systems are: 
1) dependency upon diffusion from institutions promoting or willing to support RWHS implementation

2) insufficient funds to support the whole community which can create community conflict

3) certain institutions support specific technologies thus not utilizing local resources or knowledge

Though RWH presents challenges, it continues to be promoted throughout Mexico as a decentralized approach to meet demands of water quantity and quality in rural regions. It is critical that implementing agencies ensure optimal water quality of captured and stored rainwater as well as tailor the RWHS design to meet the users water demands. This research aims at addressing this need by determining the water quality of rainwater in existing tanks and the feasibility and reliability of RWHS technologies dependent upon social and environmental factors.

\subsection{Study Site and Methods}

\subsubsection{Study Site: San Jose Xacxamayo}

The study took place in San José Xacxamayo (Figure 3.2) a small rural community of 827 people, situated southeast in the municipality of Puebla, Mexico. The community is located at an elevation of 2,000 meters above sea level $\left(18^{\circ} 55^{\prime} 48^{\prime \prime},-98^{\circ}\right.$ $14^{\prime} 48^{\prime}$ ), in a temperate semi-humid zone (INEGI, 2010). The annual precipitation is approximately $724 \mathrm{~mm}$ and highly seasonal; the rainy season lasts from the months of May to October (CONAGUA, 2012).

The community is separated from the municipality of Puebla by Lake Valsequillo, which as a consequence of its remote location and high costs to transport water is not connected to a centralized water supply system, leaving the community in charge of 
securing and managing their own water resources. However, the community struggles to secure water for their daily use because of high poverty, limited infrastructure, and time allotted for daily activities required in securing water (Figure 3.3).

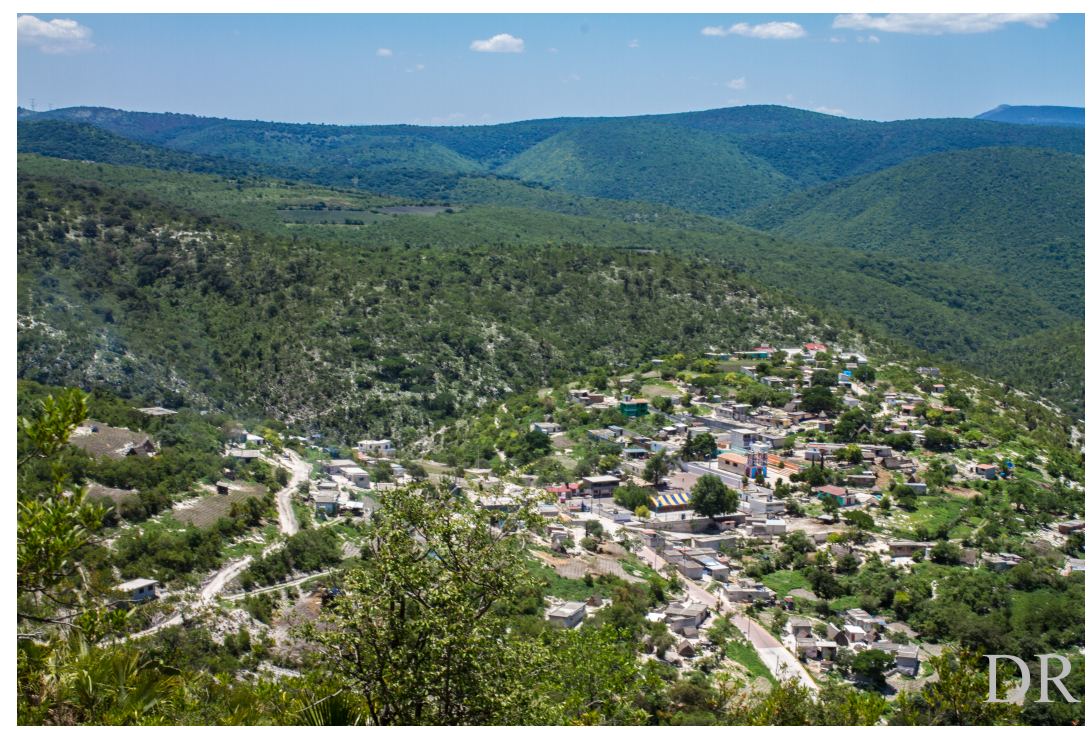

Figure 3.2: San Jose Xacxamayo located in Puebla, Mexico (Photo: Diego Rodrigo)

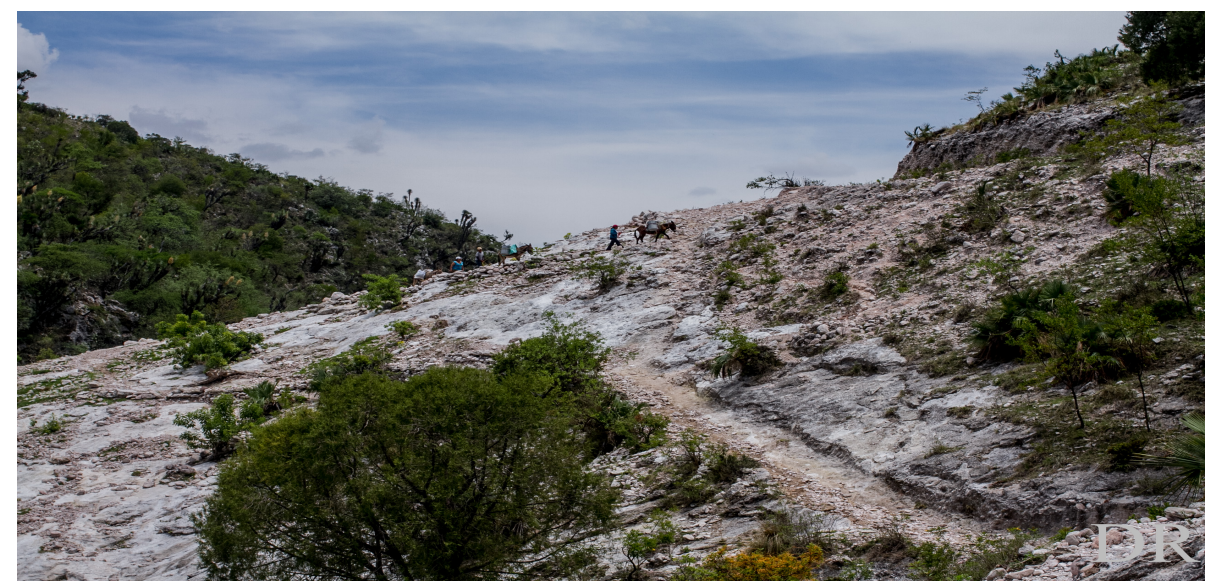

Figure 3.3: Current water challenges of daily commute to obtain water from well, for some totaling $3 \mathrm{~km}$ (Photo: Diego Rodrigo)

The DRWHS, implemented at the household level, have been used in parts of the community as a long-term, economical, sustainable solution to meet daily water demands in the rainy season. However, during the dry season, people rely on other water sources to 
meet their needs such as: chorro, headwater (transported over 10km into their town into a communal cistern), water purchased water from truck tanks, wells, and a jaguey. The chorro as shown in Figure 3.4 is the furthest water source and is excess water the spills from a tank that carries clean water to the neighboring community. The jaguey (Figure 3.5) installed in 2005 by the local government is a water storage system that collects mountain top rainwater with a capacity of over 700,000 liters. There are two wells that were constructed by Living Water International, an NGO from the United States, and one is shown in Figure 3.5. These available water sources are unreliable, more costly, and have higher susceptibility to contamination as opposed to RWHS.

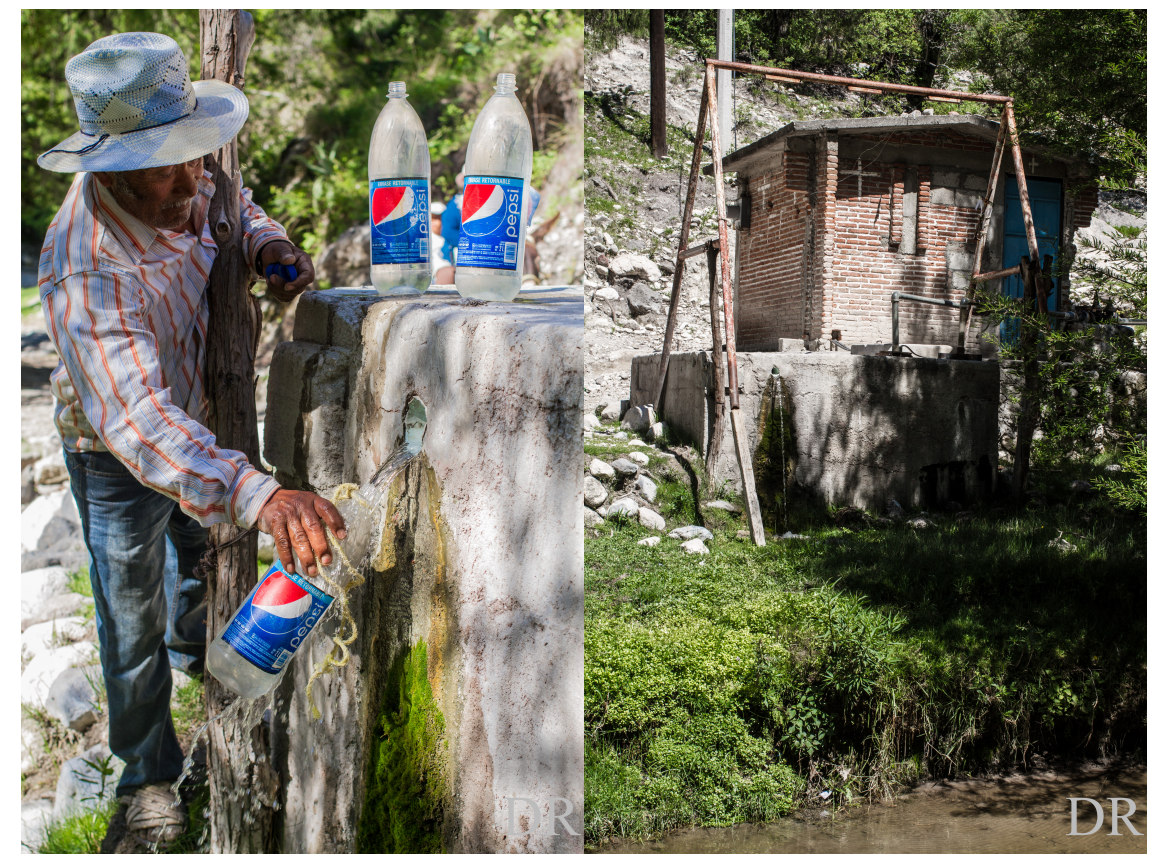

Figure 3.4: Chorro, the furthest water source available (Photos: Diego Rodrigo) 


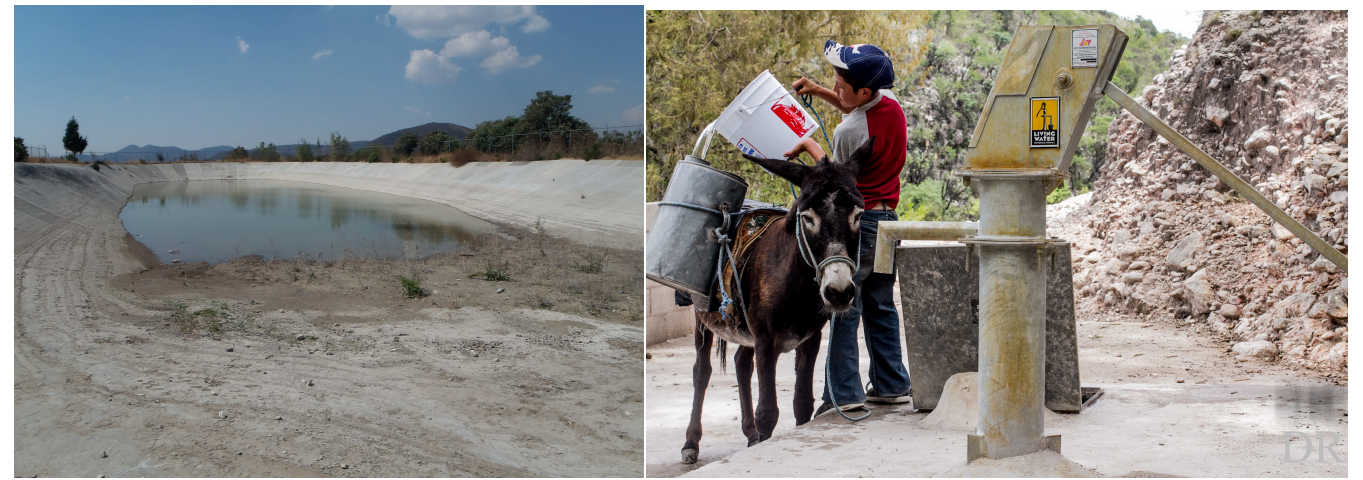

Figure 3.5: Local water sources. Left: Jaguey, a collection for mountain rainwater. Right: A well where young kids are responsible for water collection. (Photo Left: Elena Neibaur, Photo Right: Diego Rodrigo)

\subsubsection{Methods}

The methods for this study included: i) surveys of users with DRWHS ii) water quality sampling of stored rainwater and iii) water balance modeling to determine current and future reliability. There were 50 out of 70 households that participated in a DRWHS program as part of my Peace Corps service that were randomly selected for the surveys and 17 of those 50 surveys were selected for the stored rainwater analysis with user information that the stored rainwater was solely rainwater, as some users store other water sources in their tanks during the dry season.

\subsubsection{Social Feasibility Assessment}

The surveys (Appendix A) were developed in alignment with the first objective of this research: to investigate the social acceptability factors and the usage, durability, and maintenance of RWHS. The structured surveys were conducted in personal interviews to quantify systematically the social acceptability factors depending on cultural behaviors, attitudes, and skill level of household users with respect to DRWH. The survey consisted of questions pertaining to the socioeconomic characteristics, economic costs of local 
water sources, and DRWH practice, perception and dependability by the user. The data were analyzed using descriptive statistics with the Statistical Package for Social Science (SPSS) software system. The survey data also established the durability and required maintenance of existing rainwater harvesting structures within the community and the defining social factors. In addition, the surveys were used to determine the current and future potential storage capacity and reliability of RWHS based on roof size and the current domestic water demand that addresses objective 3 of this research.

\subsubsection{Water Quality Feasibility Assessment}

The water quality feasibility is defined as the physiochemical and bacteriological quality of rainwater, an important factor in deciding whether to utilize RWHS for domestic use (Baguma et al., 2010). The water quality study was conducted to inform whether using stored rainwater was advisable for domestic use. The importance of adhering to quality of water standards is necessary to limit exposure to infectious diseases. The criteria for water quality for this study were taken from the guidelines of World Health Organization (WHO) for water use and human consumption. For absence of criteria standards from $\mathrm{WHO}$, previous rainwater quality studies were compared and analyzed. The selected water quality indicators that were chosen are those that could be affected by likely exposure to contaminants in this rural setting as well as access to resources to perform analyses: (temperature, $\mathrm{pH}$, total dissolved solids, electric conductivity, ammonium, phosphorus, heterotrophic plate count, and total coliform count).

To determine the rainwater quality in RWHS, 17 rainwater samples were collected and analyzed from surveyed participants of RWHS in San Jose Xacxamayo. 
Analyses of physiochemical and bacteriological characteristics were performed from August to October of 2014. Most water samples were tested and collected directly from the RWHS, however, there were a few cases where the water levels were low and a bucket, that is the usual methods of extraction, was utilized. All samples taken were stored in sterilized polyethylene plastic containers. The samples that were not analyzed in situ were stored in a cooler of $4^{\circ} \mathrm{C}$ and transported the same day for analysis at a laboratory facility at a local university, Meritorious Autonomous University of Puebla (BUAP). The following sections briefly summarize the parameters analyzed with a brief background, the WHO standard or recommendations, and methodology for each parameter analyzed.

\section{Temperature}

Water temperature can affect the taste and quality of drinking water. Cooler water temperature tends to be preferable than warm water for drinking purposes. Warm water temperatures can lead to corrosion of pipes and enable the growth of microorganisms (A. K. Daoud et al., 2011, WHO, 2008). The water temperatures for all rainwater samples were taken in situ using Hanna instrument HI98129.

$p H$

The $\mathrm{pH}$ is determined by the concentration of hydrogen ion $[\mathrm{H}+]$ in a solution. Acidic substances have a higher concentration of hydrogen ions and basic or alkaline substances have a low concentration. The soil and material of the tanks can influence the alkalinity of a solution. The WHO recommended range for user taste preference and environmental benefits are 6.5-8.5. The Hanna Instruments HI98129 was used to measure the $\mathrm{pH}$ and was calibrated every time before usage. The calibration was conducted by 
using two known standard buffer solutions of $\mathrm{pH} 4.01$ and $\mathrm{pH}$ 7.01. The $\mathrm{pH}$ probe on the instrument was rinsed with distilled water between measurements. The $\mathrm{pH}$ probe was soaked a pH 4 buffer solution when not in use.

\section{Total Dissolved Solids}

Total dissolved solids (TDS) measure the amount of small organic matter and inorganic salts preset in water (WHO, 2003). The TDS found in water supplies can have resulted from natural sources as well as anthropogenic sources such as agricultural runoff and sewage. Although TDS is not associated with health risks alone, high TDS concentrations can serve as carriers for toxins, which readily attach to suspended solids (EPA, 2006). In addition, TDS can affect appliances and taste. Water pipe distribution systems and other appliances tend to corrode with TDS levels greater than $500 \mathrm{mg} / \mathrm{l}$. Total dissolved solids can directly affect the palatability of drinking water, with mineral contents that are extremely low $(<100 \mathrm{mg} / \mathrm{l})$ and high mineral content $(1200 \mathrm{mg} / \mathrm{l})$, rendering the water unacceptable (Kozisek, 2005; WHO, 2003). The Hanna Instruments HI98129 was used to measure TDS and was calibrated before usage, using electric conductivity calibration.

Electric Conductivity $(\mu \mathrm{S} / \mathrm{cm})$

Electric conductivity (EC) measures the water's ability to carry an electrical current; high concentrations of dissolved solids result in high conductivity. Electric conductivity is directly related to the TDS concentration in water and is influenced by the temperature of water, increasing conductivity with higher temperatures. The composition of an area can change the water conductivity when water comes in contact through passage. For example, water that passes through granite bedrock has lower conductivity 
because of the lack of ionizing materials that come in contact with water, whereas clay soils increase water conductivity because of ionizing minerals that are present in clay. Sewage systems that enter water bodies can increase the EC because of presence of phosphates, nitrates, and chloride (EPA, 2006). The Hanna Instrument HI98129 was used to measure EC and was calibrated before use with $1413 u \mathrm{~S}$.

\section{Ammonium $\left(\mathrm{NH}_{4}-\mathrm{N}\right)$}

Ammonium nitrogen $\left(\mathrm{NH}_{4}-\mathrm{N}\right)$ occurs as both ammonium ions and ammonia, existing as a pH-dependent equilibrium (Millipore, 2013). Ammonia nitrogen occurs nearly entirely as ammonia in strong alkaline solutions. High amounts of ammonia can be an indicator of fecal pollution (WHO, 2003). Ammonia concentration of $.2 \mathrm{mg} / 1$ or more when combined with chlorine can reduce the amount of free chlorine, resulting in decreased disinfection efficiency as well as taste and odor problems (WHO, 2003). In some water supplies, cement mortar, a mixture of sand and cement, can be released into the drinking water, which can compromise the efficiency of disinfection of chlorine. To carry out this analysis, the Spectroquant ${ }^{\circledR}$ Move 100 was used $10-2000 \mu \mathrm{g} / 1$ NH4-N. Before each test a blank was prepared using $5 \mathrm{ml}$ of distilled water and 1 dose of NH41K. Proceeding, 1 dose of NH4-1K was added to all sample reaction cells with a reaction time of 15 minutes. Then tests were run using the blank and samples in the Spectroquant ${ }^{\circledR}$ Move 100. Reported values under range are below .01 mg/l.

\section{Phosphate (PO4-P)}

The test measures orthophosphate and is important with water distribution systems because phosphorus provides a protective coating to service lines and household plumbing preventing corrosion and leaching of certain metals such as copper and lead 
(Wangsness, 1994). In addition, it is used to stabilize the water quality reducing chlorine demand. Many companies add this to the water supply to prevent corrosion of distribution pipes. Anthropogenic sources of phosphate include agricultural runoff, detergents, and sewage (Wangsness, 1994). To carry out the phosphate analysis, the Spectroquant ${ }^{\circledR}$ Move 100 was used $0.5-30.0 \mathrm{mg} / 1$ PO4-P. Before each test a blank was prepared using $5 \mathrm{ml}$ of distilled water added to a $16 \mathrm{~mm}$ cell and $1.2 \mathrm{ml}$ of PO4-1 with pipette. Proceeding, $1.2 \mathrm{ml}$ of PO4-1 with pipette was added to all sample $16 \mathrm{~mm}$ cells. Then blank and samples tests were run Spectroquant ${ }^{\circledR}$ Move 100.

\section{Heterotrophic Plate Count and Total Coliform}

Heterotrophic plate count (HPC) is the measurement of heterotrophic bacteria, which are bacteria that grow with organic nutrients. These bacteria are abundant in the environment and include bacterial pathogens. There are no specific recommendations for HPC levels since heterotrophic bacteria do not pose any health risk when present in drinking water. However, monitoring of heterotrophic bacteria can be useful to determine water storage and treatment efficiency (Allen et al., 2004).

Coliform bacteria are used as an indicator of microbiological quality of water. Although not all coliform is considered harmful to human health, there are certain ones that are and are correlated with waterborne diseases. Animal and human wastes are sources of microbiological contamination. By testing for coliform, the presence of potential harmful pathogens can be detected. The WHO recommended level is 0 UFC/100ml (WHO, 2001).

Both tests were conducted in the laboratory immediately after collection. Merck Millipore's Samplers with a $.45 \mu \mathrm{m}$ filter were used, placed in an incubator for 48 hours 
at $35^{\circ} \mathrm{C}$. A count was then conducted. For coliforms results shown in blue color on the test sampler whereas non-coliforms result in green gray, or cream color. Only the blue colonies are counted and multiplied by 100 to obtain unit in CFU/100ml.

\subsubsection{Technical Feasibility Assessment}

Rainfall data were extracted from the nearest meteorological station, Balcon Diablo A. Texaluca, for a 49 year time period (1951-2010), which at least a 30-year period is recommended by the World Meteorological Organization for a minimum representative climate period.

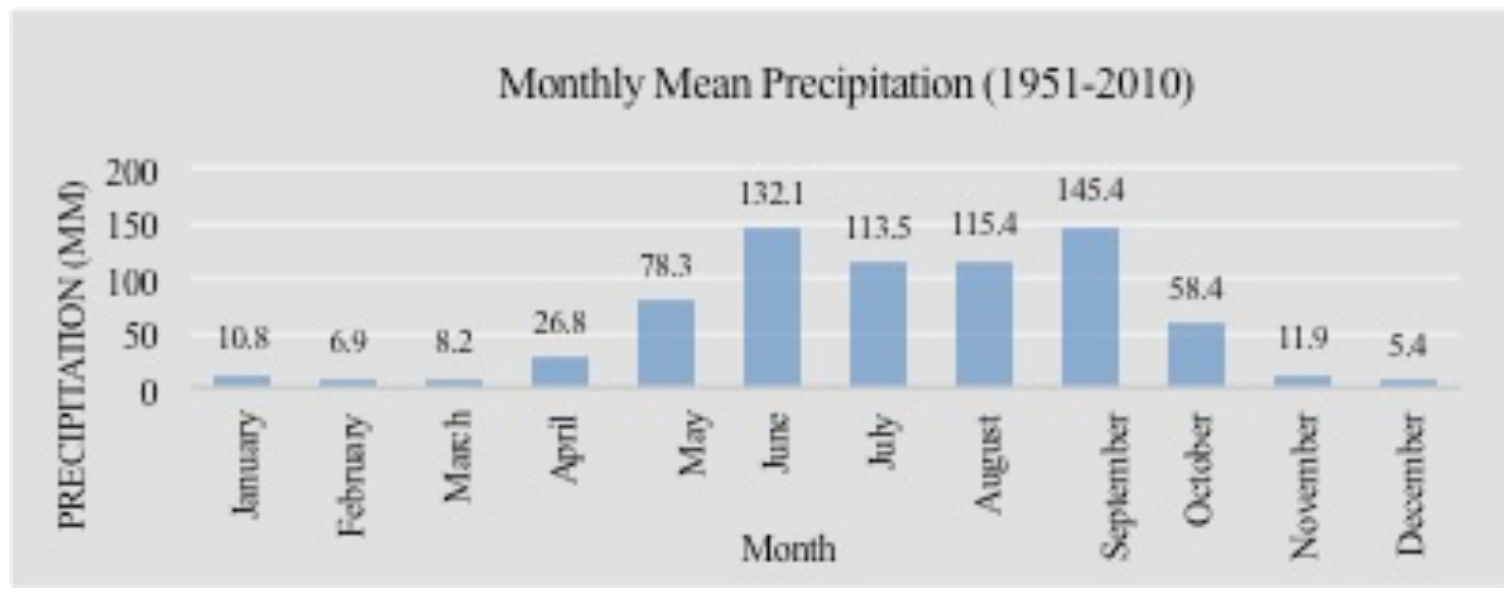

Figure 3.6: Monthly mean precipitation (1951-2010) from meteorological station Balcon Diablo A. Texaluca

\section{Domestic Water Demand Estimation}

As part of the survey, domestic water demand for weekly use was calculated. Domestic water demand is defined in three categories: 1) Consumption (drinking and cooking) and 2) Hygiene (washing clothes, bathing, washing dishes, washing the house) and 3) Amenity (watering plants) (WHO, 2004). Initially the question was for all domestic uses for the household per week. However, responses were conservative and with high uncertainties with the first 8 surveys conducted. For the additional 42 surveys 
that were carried out, the weekly domestic water demand was separately recorded for each sub-category per household, providing a more precise response by the participant. The total domestic water use for each household was used to calculate the water volume that can be captured and stored given the monthly precipitation. In addition, monthly demands and roof sizes were averaged to calculate the overall average feasibility and reliability.

\section{Water Balance Simulation Model}

Calculating the volume of potential rainwater collection is important to optimize the size of the rainwater tank for sustainable water use. The key component to a DRWHS is the catchment area, where the rainwater is captured. In San Jose Xacxamayo the rainwater is captured from the households' roof, with the majority having concrete roofs. The roof material determines the amount of rainwater collected referred to as the runoff coefficient (RC), concrete having a RC of .8 results in only $80 \%$ of rainfall to be collected. The roof runoff volume of a system can be calculated with the following equation:

\section{Equation 3.1 Roof runoff volume}

$Q_{t}=\mathrm{RC} \times \mathrm{R} \times \mathrm{A}$

Where:

$\mathrm{Q}_{\mathrm{t}} \quad$ = is the quantity of rainwater harvested $\left(\mathrm{m}^{3}\right)$ in a month or year,

$\mathrm{RC}=$ is the runoff coefficient,

$\mathrm{R} \quad=$ is the total rainfall (month or yearly), and

A $\quad=$ is the roof area or catchment area $\left(\mathrm{m}^{2}\right)$ 
The inflow, $\mathrm{Q}_{\mathrm{t}}$, is calculated using the net monthly rainfall, storage catchment size, and the runoff coefficient for the material used, which is taken to be .80 . The water mass balance model is then applied to calculate the feasibility of DRWHS to capture sufficient water for the current and future domestic household demand, the water mass balance was applied based on Fewkes (1999) approach:

\section{Equation 3.2 Water Mass Balance Equation}

$V_{t}=V_{t-1}+Q_{t}-D_{t} ; 0 \leq V_{t} \leq S$

Where:

$\mathrm{V}_{\mathrm{t}} \quad=$ Volume $\left(\mathrm{m}^{3}\right)$ of rainwater in storage at end of interval, $\mathrm{t}$

$\mathrm{Q}_{\mathrm{t}} \quad=$ Inflow $\left(\mathrm{m}^{3}\right)$ during time interval, $\mathrm{t}$

$\mathrm{D}_{\mathrm{t}} \quad=$ Demand $\left(\mathrm{m}^{3}\right)$ during time interval, $\mathrm{t}$

$\mathrm{S} \quad=$ Maximum Storage Capacity

Time is taken for the monthly storage capacity using the demand of all surveyed users and each user's current roof size was inputted in the equations. The water balance model is calculated in Excel and provides accurate results of the tanks monthly inflow, outflow, and total volume.

\section{Reliability}

The performance of DRWHS is then described in terms of reliability. The reliability is calculated by taking the total number of users that met their domestic water demand in the monthly time period as described in the following equation:

\section{Equation 3.3 Reliability of RWHS}

$R_{e}=1-\frac{n}{N} \times 100 \%$

Where: 
$\operatorname{Re} \quad=$ Probability (\%) of the tank supplying the monthly demand of the users

$n \quad=$ Number of households that did not meet their water demand for that month

$\mathrm{N} \quad=$ Total number of users

\section{DRWHS Sensitivity Analysis}

A sensitivity analysis of climate change impacts to the variability of rainfall was considered using the Climate Wizard Tool. The Climate Wizard Tool was developed by The Nature Conservancy and utilizes various General Circulation Models, as referenced from the IPCC Climate Change Fourth Assessment Report, that calculate future precipitation and temperature values for year. Future emission scenarios (A2, Alb, and b1) impacts on precipitation are considered for the RWHS reliability over 2 time scenarios: mid-century (2046-2065) and end of century (2081-2100). A regional assessment of San Jose Xacxamayo was conducted using Climate Wizard's Custom Analysis Tool and the precipitation variables were extracted from a GCM ensemble average of 9 models provided: cccma_cgcm3_1.1, cnrm_cm3.1, gfdl_cm2_0.1, gfdl_cm2_1.1, ipsl_cm4.1, miroc3_2_medres.1, miub_echo_g.1, mpi_echam5.1, mri_cgem2_3_2a.1.

The current and monthly precipitation were input to Eq. 1, Eq. 2, and Eq. 3 to calculate the household water supply fluctuation under different climatic assumptions. Then the overall performance of the DRWHS using the reliability to determined if the water supply is sufficient to meet the households' current and future demands 


\section{RESULTS}

This chapter reports the assessment results of the social, physical, and technical feasibility studies of the DRWHS from the 50 surveys conducted, 17 water analyses, and potential tank storage capacity for all 50 users under current and projected precipitation patterns. Out of the 50 surveys carried out there was $100 \%$ participation. However, some questions within the survey were not answered by participants and are noted if this is the case.

\subsection{Social Feasibility}

The present section presents the survey results of the social feasibility of DRWHS by considering the socioeconomic characteristics, economic costs of local water sources, and DRWH practice, perception and dependability by the user. The average age of the participants was 39 years old and females made up the majority (96\%) of the survey respondents due to men unavailable during the time when surveys where carried out. Out of the respondents, $96 \%$ identified as one of the head of the households. The average household size of participants is around 4.3.

Income is made up from various sources, the primary being: government support, construction, and agriculture. Construction was the main source of income for most households (66\%), agriculture was the second source accounting for $26 \%$, and $8 \%$ responded with other sources of income such as selling embroidered napkins, weaving palm boxes, selling wood or running a local store. Monthly income reported, shown in Figure 4.1 in U.S. dollars, includes any government assistance; 64\% of participants did receive such aid. Just over half (52\%) of the monthly household income of respondents was over $\$ 192$ USD $(\$ 2,500 \mathrm{MXN})$ however the upper limit was not specified. The 
second monthly income range, $\$ 39-\$ 77$ USD $(\$ 501-\$ 1000 \mathrm{MXN})$, accounted for $18 \%$ of the people surveyed and the third monthly income range \$115-\$143 USD (\$1501-\$2000 MXN) made up $14 \%$ of participants. Given the average household size this implies that nearly half the people live on less than $\$ 1.25 /$ day.

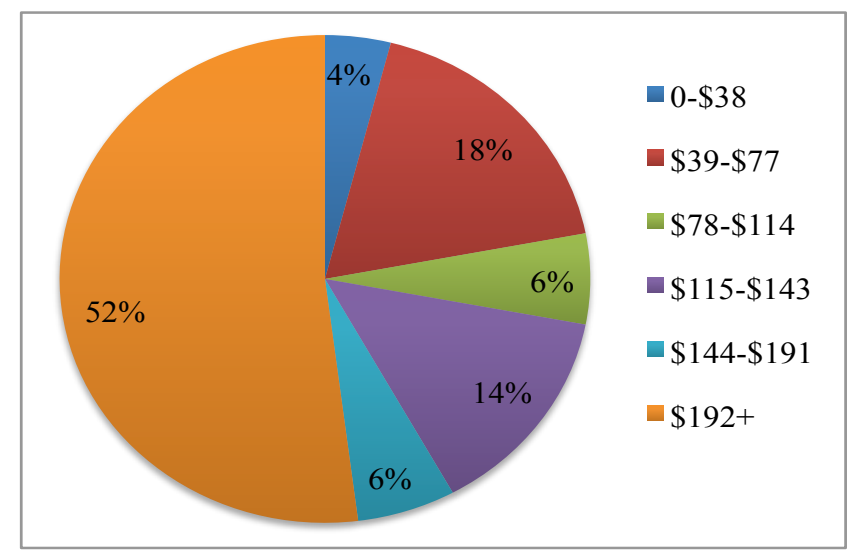

Figure 4.1: Household monthly income (USD) of participants.

All respondents (100\%) stated they have no access to potable water in their homes. Figure 4.2 depicts the type of bathroom the household uses, which relates to access to basic sanitation. Over half of the respondents use the open field as their bathroom. Only $12 \%$ have a flush toilet, which is enabled from pumping stored water to their roof tank.

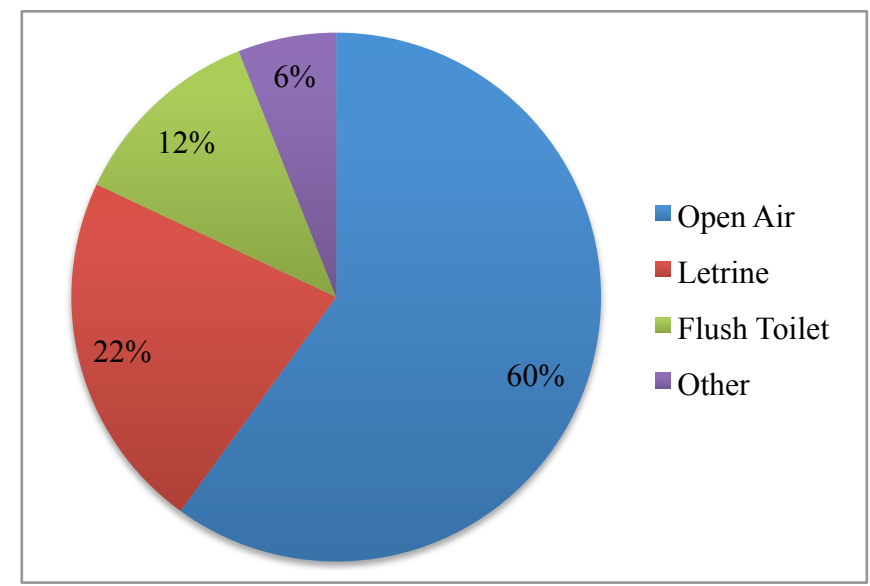

Figure 4.2: Bathroom types of household surveys respondents. 
Figures 4.3-4.6 show the results to collecting water from local available water resources (chorro, well, headwater, and jaguey) in relation to frequency, time spent each collection trip, and the responsible party. All participants responded that they do not use the jaguey because of the poor quality of water and inconvenient location. Figure 4.3 shows which water sources are highly relied upon out of those who collect water by foot. Over three fourths of all users collect from the headwater (74\%) and well water (70\%) for domestic uses. Few (26\%) of all surveyed users collect water from the chorro.

Figure 4.4 shows the number of households that collect water through these local sources by foot and the frequency by the household. All 50 surveyed users reported that there are only three months out of the year where water is not collected by foot by the household. The weekly travel frequency to obtain water was answered by 49 out of the 50 respondents where the amount of days travelled per week varied from only 1 day to all 7 days. Most frequently users travel once or twice a week to obtain water from local sources. Respondents also noted that most of the weekly travel is done in the dry season (November-April).

Figure 4.5 represents the collection time from those respondents who reported they collect water by foot from local sources. The chorro takes users the most time to obtain water, reaching up to $90+$ minutes round-trip. More users use the headwater, which is the least average time spent, ranging from 0-39 minutes. Figure 4.6 shows the majority of the male heads of households are responsible for water collection (43\%), however children play a big role as well (34\%). The other category accounts for people outside of the household where some reported that neighboring kids are paid to collect water. 


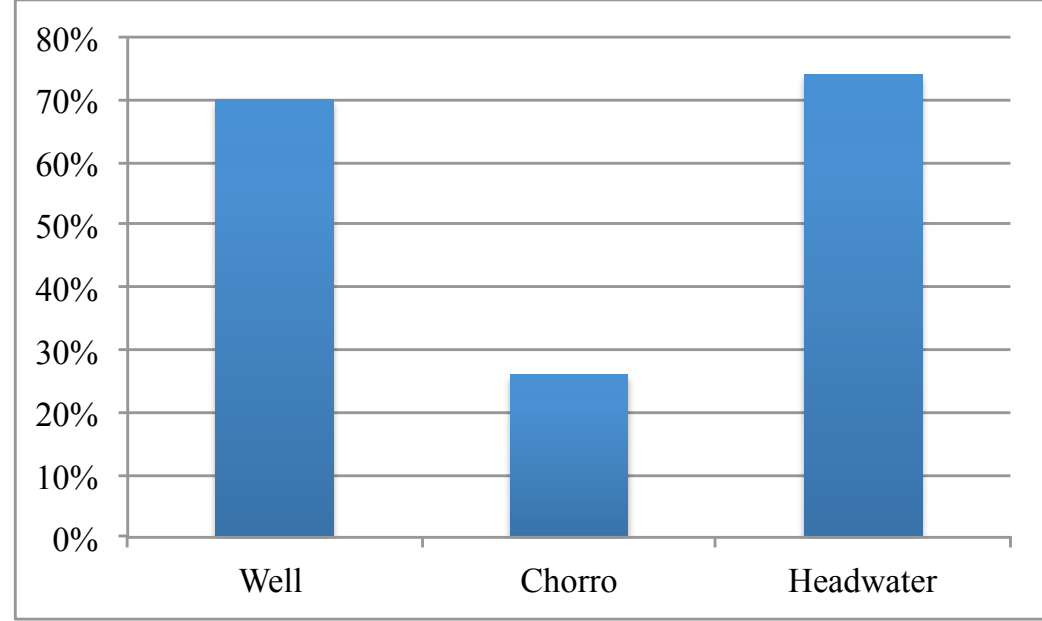

Figure 4.3: Percent of users who use and collect local water sources by foot for domestic use.

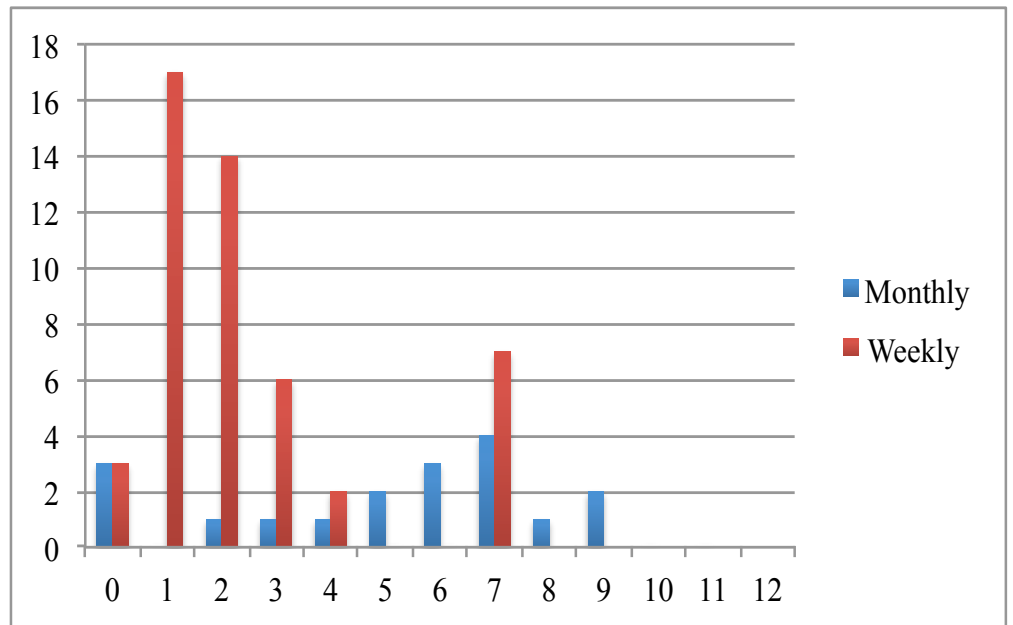

Figure 4.4: Frequency of days and months spent for water source collection.

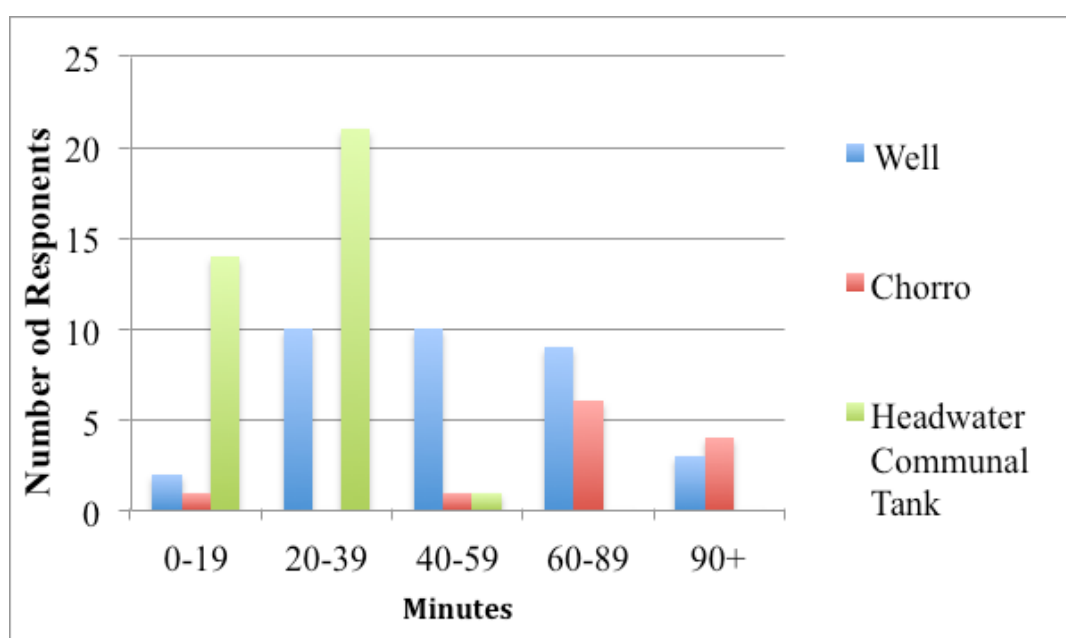

Figure 4.5: Collection time spent for local water sources.

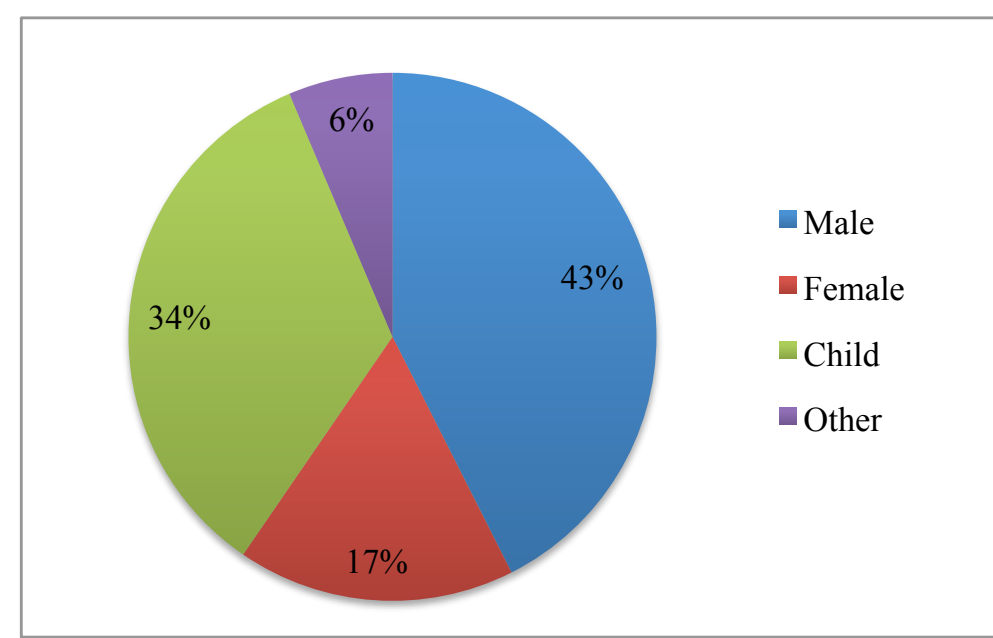

Figure 4.6: Burden of collection for local water sources where other accounts for people outside the household. 
Out of all users, 12 responded that they do not use rainwater for drinking where the other 34 responded that they do. Participants were asked to rank dependency of their available water sources (jaguey, wells, purchased water, chorro, headwater, and rainwater) in order of reliance and usage for domestic purposes; 26 (52\%) of respondents ranked rainwater as number 1, the most used, $18(36 \%)$ ranked it second, $5(10 \%)$ ranked it third, and 1 respondent said they do not use it. All respondents claimed they do not use the jaguey.

Table 4.1 shows the perception of rainwater amongst the 49 participants who collect and store it. The majority stated that the smell, appearance, and taste are average or above average. One of the users had a bad perception of the rainwater but that user declared that they do utilize rainwater for drinking.

Table 4.1: Perception of Rainwater

\begin{tabular}{cccc}
\hline Category & Description & N & Percentage \\
\hline \multirow{3}{*}{ Smell } & smells good & 49 & $24 \%$ \\
& doesn't smell & 49 & $73 \%$ \\
& smells bad & 49 & $2 \%$ \\
Appearance & transparent & 49 & $59 \%$ \\
& not that dirty & 49 & $39 \%$ \\
& dirty & 49 & $2 \%$ \\
Taste & taste good & 49 & $49 \%$ \\
& taste ok & 49 & $37 \%$ \\
\hline
\end{tabular}

All participants have a DRWHS, and only one user does not collect rainwater because of their roof type (woven palm thatch). Table 4.2 shows select characteristics from the existing systems that participants have (age and cost of tank, user contribution to tank construction, and required maintenance). The two types of cisterns that are shown and utilized in the community are concrete and ferrocement. There are other ways the 
community captures rain such as plastic and metal containers but these are not accounted for because of small size (200-1500 liters) and inability to alone supply sufficient water for the household. There are more concrete tanks (69) compared to ferrocement tanks (7). Over half of the tanks (55\%) were federally funded and a large number of participants were financially responsible for their own tank (37\%). Most households have to contribute with time and/or money regardless of the financial funding source of the tank. The average reported cost contribution by the user per tank is $\sim \$ 221$. In most cases the household participates in the construction process both digging the hole and constructing the tank or helping. The average number of days for digging a concrete cistern (12.6) is higher than that of a ferrocement (2.33) since ferrocement are aboveground structures. The construction process for both averages about 13 days for each system. The tank age ranges from $<1$ year to 18 years, with $38 \%$ representing tanks that have been in existence for over 6 years which happens to be concrete tanks. The maintenance requirement for concrete tank is low $(9 \%)$ with the average tank age that requires maintenance is 9 years and average total spent on repairs is $\$ 50$. The ferrocement tank has a higher maintenance requirement (42\%) with an average tank age of 1.6 years and average total spent on repairs is $\$ 12.40$. Out of the 46 who responded to maintenance capability all reported that their family is capable of maintaining their RWHS if there is a malfunction (i.e., leak). 
Table 4.2: DRWHS characteristics

\begin{tabular}{|c|c|c|c|c|}
\hline Category & Description & Concrete & Ferrocement & Total \\
\hline $\begin{array}{l}\text { Number of } \\
\text { Cistern }\end{array}$ & DRHWS & 69 & 7 & 76 \\
\hline \multirow{3}{*}{ Government Aid } & No Aid & 28 & 0 & $28(37 \%)$ \\
\hline & International Aid & 6 & 0 & $6(8 \%)$ \\
\hline & Federal Aid & 35 & 7 & $42(55 \%)$ \\
\hline \multirow{4}{*}{ Economic Costs } & $<\$ 100$ & 24 & 0 & 24 \\
\hline & $\$ 100-\$ 500$ & 14 & 3 & 17 \\
\hline & $\$ 501-\$ 1000$ & 6 & 0 & 6 \\
\hline & $>\$ 1000$ & 1 & 0 & 1 \\
\hline \multirow{3}{*}{$\begin{array}{c}\text { Labor } \\
\text { Contribution } \\
\text { (*Avg. No. Days) }\end{array}$} & Digging & 12.6 & 2.33 & \\
\hline & Construction & 12.3 & 15 & \\
\hline & $<1$ & 5 & 1 & 6 \\
\hline \multirow{3}{*}{$\begin{array}{c}\text { Tank Age } \\
\text { (Years) }\end{array}$} & $1-5$ & 35 & 6 & 41 \\
\hline & $6-10$ & 19 & & 19 \\
\hline & $11-18$ & 10 & & 10 \\
\hline \multirow{4}{*}{ Maintenance } & No. of tanks repaired & $6(9 \%)$ & $3(42 \%)$ & $10(13 \%)$ \\
\hline & Avg. repaired tank age & 9 & 1.6 & 5.3 \\
\hline & Avg. total repairs & 1.8 & 1.5 & 1.65 \\
\hline & Avg. repair costs & $\$ 50$ & $\$ 12$ & $\$ 31$ \\
\hline
\end{tabular}

*Average total number of days required to build a DRWHS

\subsection{Water Quality Feasibility}

Water quality feasibility was defined in terms of physicochemical and bacteriological quality. Following are the 17 water quality parameters results (Table 4.3) of the rainwater that was captured and stored by the participants. All of the users stated that the water collected in the RWHS was cleaned out prior to the rainy season and is pure rainwater (no cross source contamination). 
Table 4.3: Water Quality Parameters

\begin{tabular}{llll}
\hline Parameter & Range & Mean & WHO Guidelines \\
\hline Temp $\left({ }^{\circ} \mathrm{C}\right)$ & $17.1-22.2$ & 19.81 & - \\
$\mathrm{pH}$ & $7.7-10.42$ & 8.74 & $6.5-8.5$ \\
Conductivity $(\mu \mathrm{S} / \mathrm{cm})$ & $33-176$ & 97.4 & - \\
TDS $(\mathrm{ppm})$ & $23-123$ & 67.9 & $100-1200$ \\
Ammonia $(\mathrm{mg} / \mathrm{l})$ & $<0.01-0.245$ & 0.069 & $<0.2^{*}$ \\
Phosphate $(\mathrm{mg} / \mathrm{l})$ & $0.3-0.9$ & 0.55 & - \\
Total Coliform $(\mathrm{CFU} / 100 \mathrm{ml})$ & $0-500$ & 82 & 0 \\
HPC $(\mathrm{CFU} / \mathrm{ml})$ & $57-10780$ & 1209 & - \\
\hline
\end{tabular}

*Recommended level with chlorine present

Temperature and $\mathrm{pH}$

The temperature sampled ranged from $17.1-22.2\left({ }^{\circ} \mathrm{C}\right)$, with an average of $19.81\left({ }^{\circ} \mathrm{C}\right)$. The $\mathrm{pH}$ of the rainwater samples resulted in basic $\mathrm{pH}$ ranging from 7.93 to 10.42. Roughly $53 \%$ of the samples were within the WHO recommended standard of $\mathrm{pH}$ 6.5 to 8.5 .

$T D S$

The TDS of samples ranged from 23ppm to $123 \mathrm{ppm}$ with an average of $67.8 \mathrm{ppm}$. Although there is no WHO standard, it is generally recommended for TDS to be between 100-1,200ppm for drinking water. Of the samples, only two exceeded 100ppm.

\section{Electric Conductivity}

Electric conductivity is directly correlated to TDS. The EC results ranged from 33-176 $\mu \mathrm{S} / \mathrm{cm}$ with a mean of $97.4 \mu \mathrm{S} / \mathrm{cm}$. There are no WHO recommended EC levels.

\section{Ammonia}

Ammonia ranged from less than $.01 \mathrm{mg} / 1$ to $.245 \mathrm{mg} / 1$ with a mean of $.069 \mathrm{mg} / \mathrm{l}$. Although there are no WHO recommended ammonia levels, those who have ammonia 
greater than $.2 \mathrm{mg} / \mathrm{l}$ can interfere with the effectiveness of chlorine. Which it was reported that two participants' tanks had water with ammonia greater than $.2 \mathrm{mg} / \mathrm{l}$. Additionally, two samples' results were under range signifying level lower than .1 mg/l.

\section{Phosphate}

The phosphate ranged from .3-.9 with an average of .55. There were 5 users with

phosphate values under range implying levels lower than $.5 \mathrm{mg} / \mathrm{l}$. There are no WHO recommended phosphate levels.

\section{Heterotrophic Plate Count}

The HPC count was high amongst all users. Only one user had below 100 $\mathrm{CFU} / \mathrm{ml}$ at a value of $70 \mathrm{CFU} / \mathrm{ml}$. There are no WHO recommended HPC levels.

\section{Total Coliform}

Four users had coliform bacteria present in their drinking water, but the majority did not. Of those with coliform bacteria present three did not use treatment in the storage tank where one treated with chlorine.

\section{Water Quality and Social Factors}

Social factors that have been reported to affect water quality are the age of the selected cistern design coupled with DRWHS maintenance. There seems to be a correlation of HTP count with frequency of roof cleaning and total coliform count with frequency of cleaning the cistern. The more frequent the participants reported that they cleaned the roof the lower the HTP count and the more frequent the cistern was cleaned showed a relationship with a lower coliform bacteria count. 


\subsection{Technical Feasibility}

The water balance model was used to determine the technical feasibility and considers the following factors: rainfall input, catchment size, runoff coefficient (.8), and household domestic water demand. Rainfall variability of the emission scenarios (A2, $\mathrm{A} 1 \mathrm{~b}$, and B1) is depicted in Figure 4.7 with B1 scenario yielding the most amount of annual average precipitation for the mid-century and end of century. Both A2 and A1B scenarios average the least amount for annual precipitation.

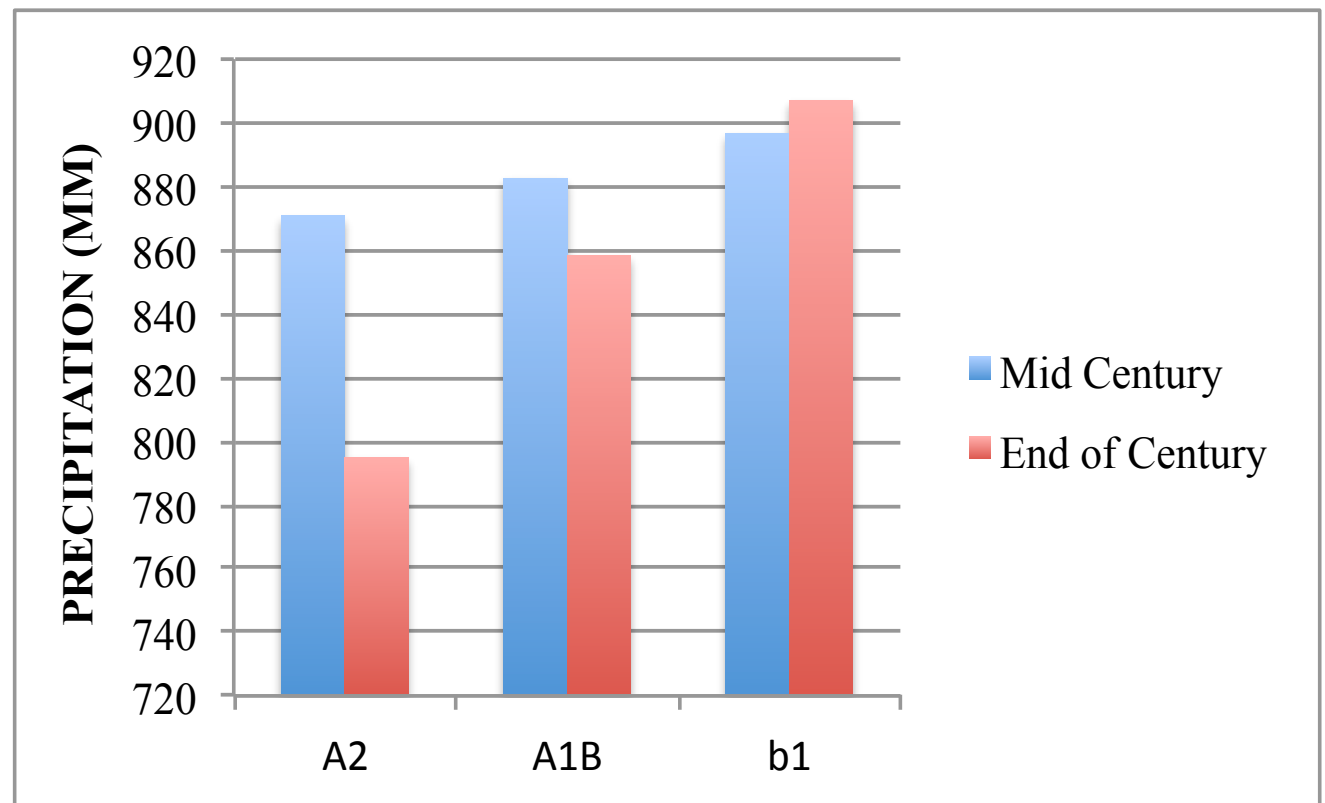

Figure 4.7: Mean annual precipitation variability under climatic scenarios (A2, Alb, b1)

Figure 4.8 demonstrates the monthly variability under all scenarios (current, A2, Alb, and B1) with B1 clearly shown as the scenario that would receive the most rainfall. All scenarios have the same temporal variability with an increase of precipitation starting in April and declining significantly in October, thus seasonality is not affected over all three emission scenarios. 


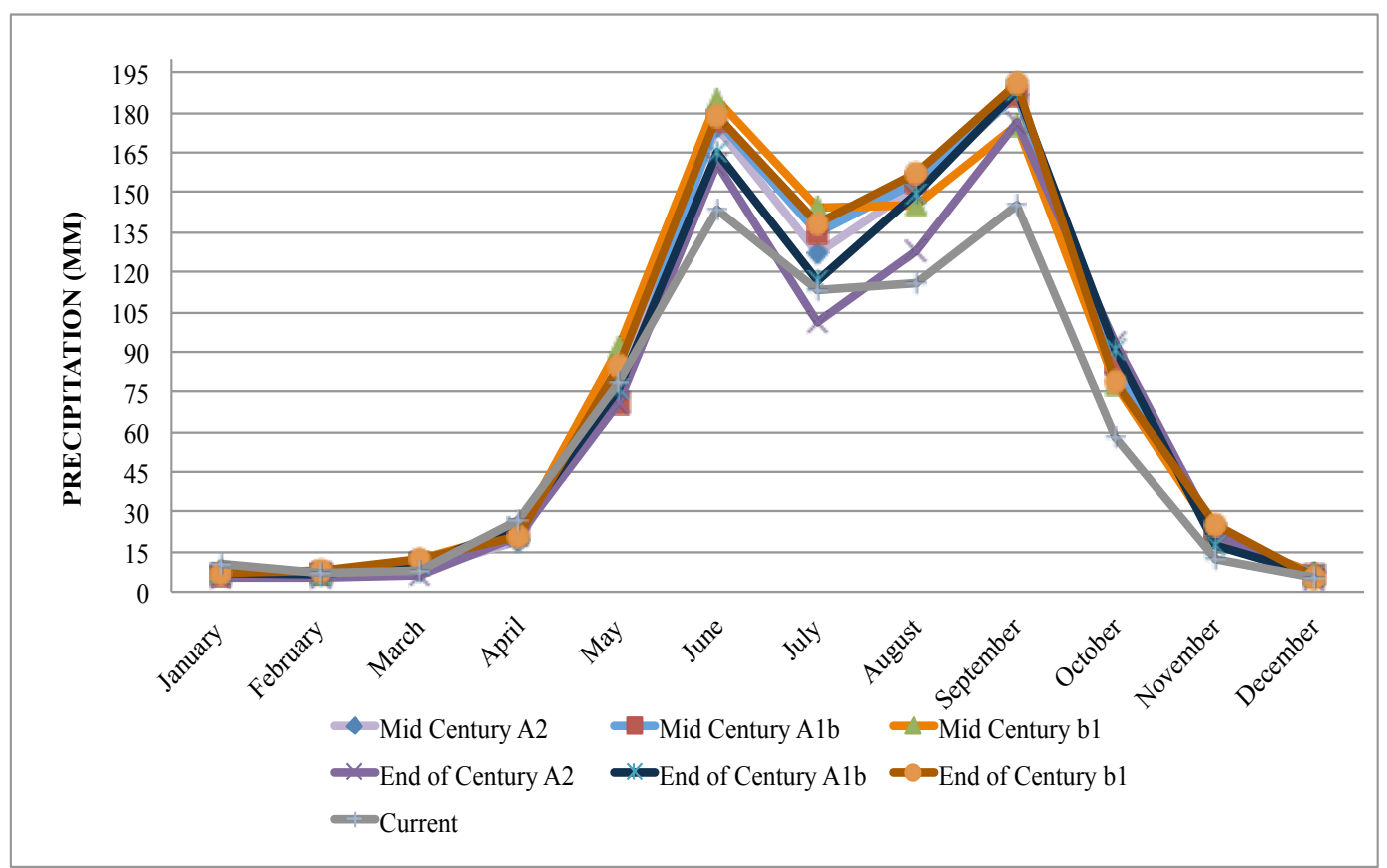

Figure 4.8: Monthly average precipitation for current and future Climatic Scenarios (A2, A1b, b1)

The participants' household domestic weekly water demand per category is demonstrated in Figure 4.9. Washing clothes and bathing combined make up over half $(60 \%)$ of household water use. The average domestic weekly water demand of all households surveyed was 1693.17 liters, which equates to 56.78 1/c/d (21.4 $\mathrm{m} 3 /$ capita/year). This is below the WHO recommended minimum of $100 \mathrm{l} / \mathrm{c} / \mathrm{d}$ and just above the WHO poverty threshold $50 \mathrm{l} / \mathrm{c} / \mathrm{d}$. 


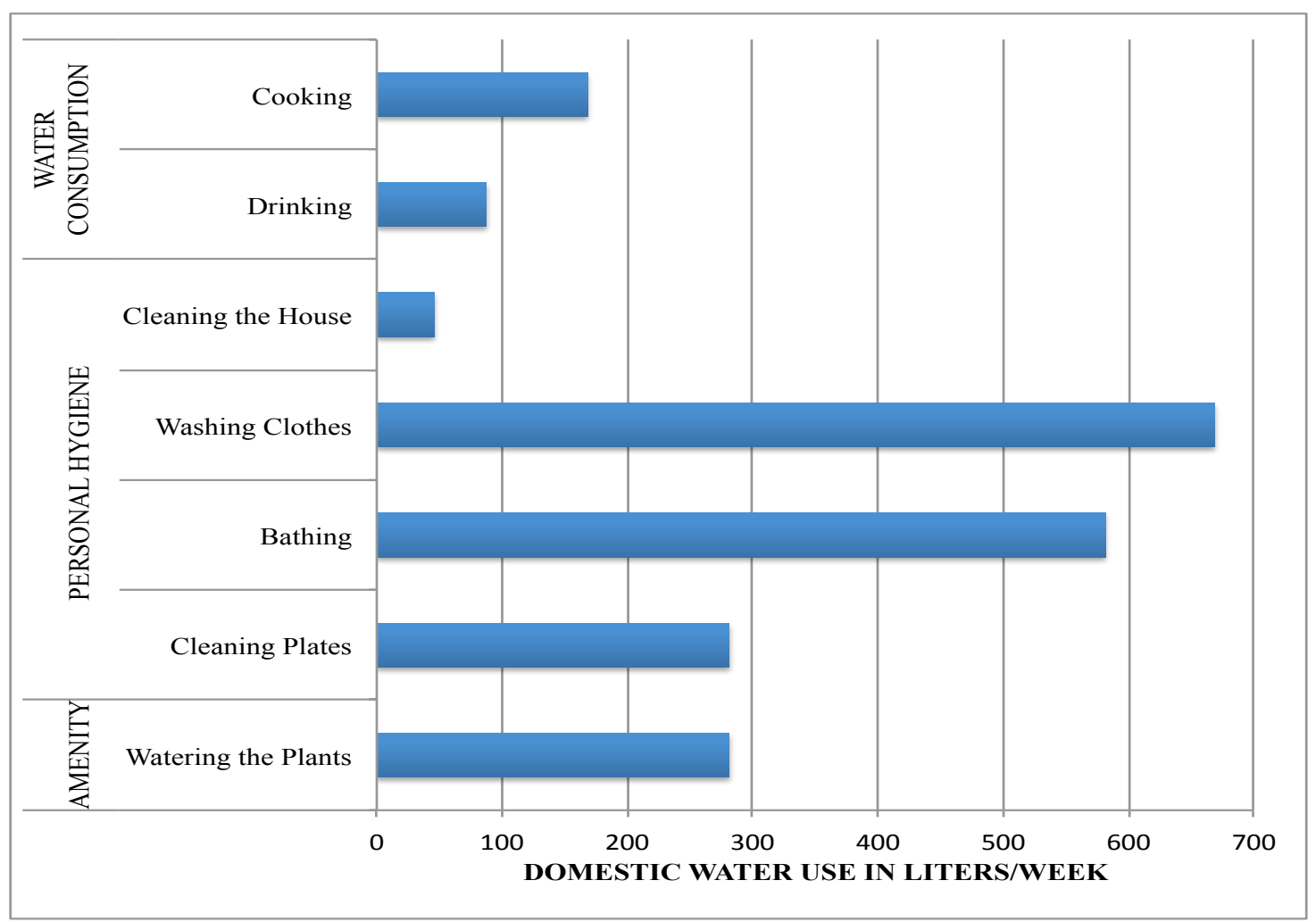

Figure 4.9: Average domestic water consumption (liters) in San Jose Xacxamayo

\section{Reliability}

Appendix $\mathrm{C}$ shows the calculations used in the water balance model for each household that determined the total amount each user could collect given their water demand, roof size, and the current and future precipitation fluctuations. These results were used to determine the reliability of the DRWHS for current and future precipitation scenarios.

The Mid-Century (2046-2065) reliability shows the percentage of users whose demands are met in the monthly time period, demonstrated in Figure 4.10. DRWHS under current precipitation scenario is less reliable that of the future scenarios $(\mathrm{A} 2, \mathrm{~A} 1 \mathrm{~b}$, b1). The optimal scenario for the community would be b1 due to higher volume of rainfall. Regardless, under all scenarios the overall monthly reliability is below $80 \%$ and less than $50 \%$ for the dry season. 
The End of Century (2081-2100) reliability is demonstrated in Figure 4.11. DRWHS under current precipitation scenario is more reliable for eight months out of the year than the other emission scenarios. The most reliable emission scenario is b1 in the rainy season and A2 in parts of the dry season. The overall reliability for all months and scenarios is below $70 \%$ for the rainy season and $30 \%$ for the dry season.

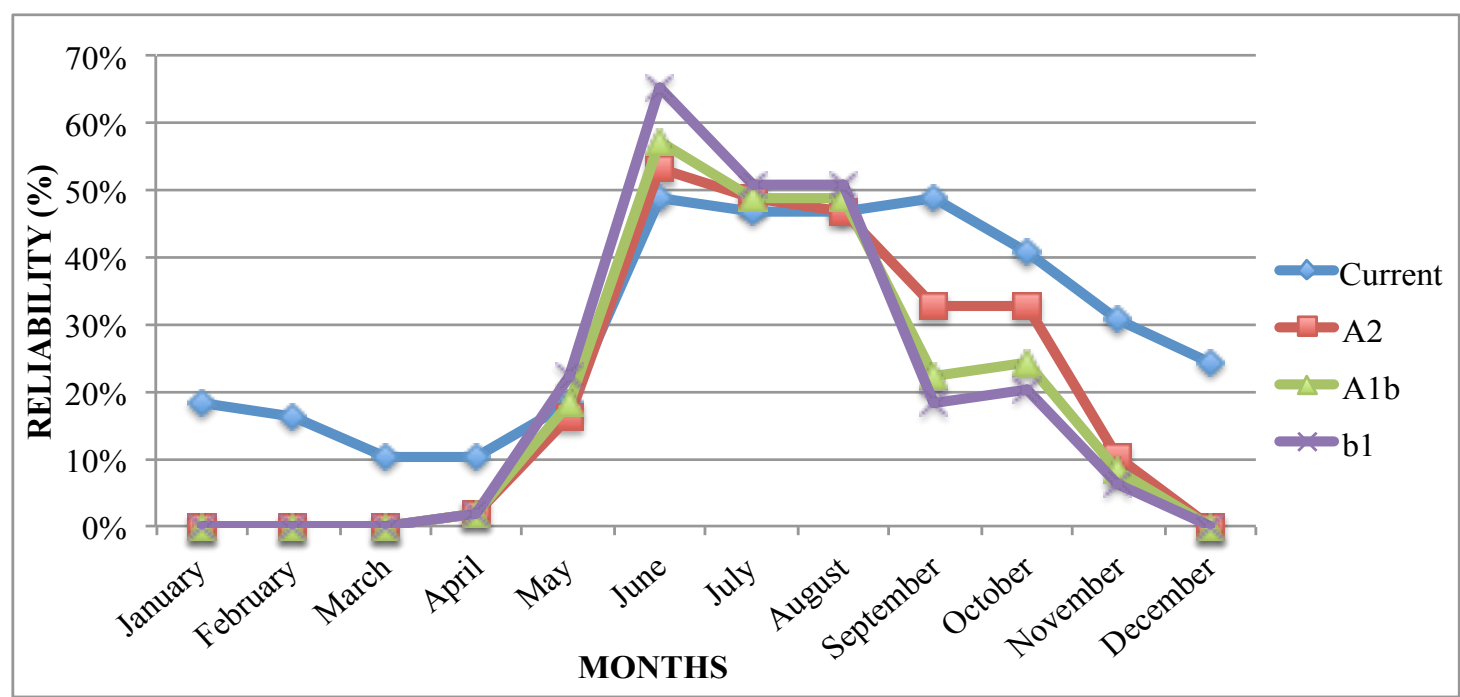

Figure 4.10: Mid-Century (2046-2056) reliability of DRWHS under current and future precipitation patterns (A2, Alb, b1)

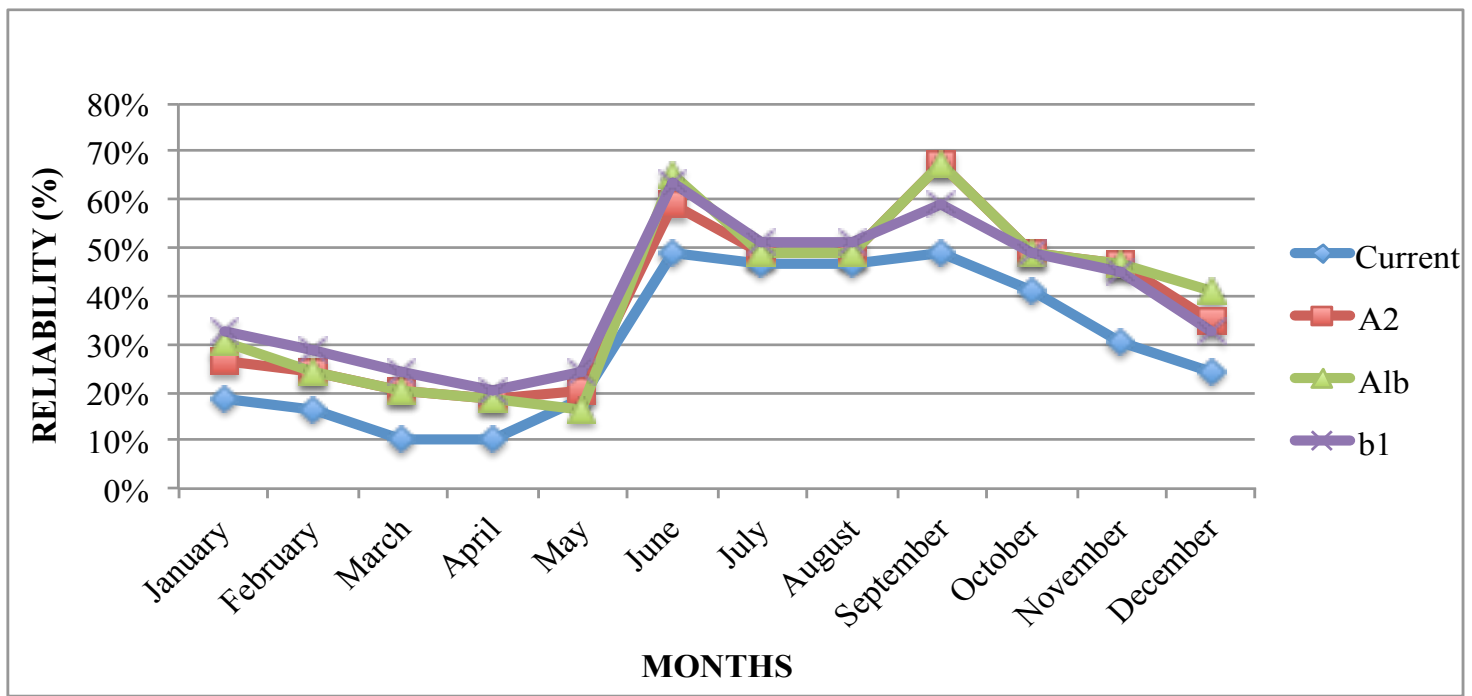

Figure 4.11: End of Century (2081-2100) reliability of DRWHS under current and future precipitation patterns $(\mathrm{A} 2, \mathrm{A1}$ b, b1) 


\section{DISCUSSION}

The most important contribution of this study is that roof sizes were determined to be the main limiting factor of the sustainability of the rainwater systems to meet year-round water demands for domestic use in rural, semi-arid areas. It is recommended to have a roof size of at least $150 \mathrm{~m}^{2}$ for rural, semi-arid communities in developing countries, to supply sufficient quantity of water for annual household domestic demands. In addition, because of coliform bacteria present in four of the rainwater systems, adequate management of roof and cistern cleanliness and further treatment after rainwater capture and storage is required to make the rainwater potable for household use. This study also highlights the importance of community involvement from the planning, implementation, and maintenance phases in order to meet the social feasibility and ensure the DRWHS do not fail.

\subsection{Social Feasibility}

Most communities, when faced with a new technology or practice, are reluctant to adopt these changes primarily due to economic constraints, cultural perceptions, insufficient knowledge and limited skills to implement and/or operate the system. Half of the self-financed systems came from the respondents who had a low income $(<\$ 1.25 /$ day/capita $)$, thus income was not a limiting factor in self-financing their own systems. The ability to self-finance their own DRWHS can be attributed to the fact that many households had males that were skilled construction workers, thus they were able to save about $1 / 3$ of the total cost of the system. The community members of San Jose Xacxamayo readily accepted and adopted DRWHS primarily due to necessity of water 
for basic needs. Their acceptance and reliability of DRWHS is demonstrated through the current life span of existing systems. However, there exists a need for a modification on the existing DRWHS in order to supply water year round, this is evident in the percentage of users who collect water from other sources throughout the year. This is temporarily variable, with three of the months showing that the respondents do not collect water by foot, implying that most likely they have sufficient rainwater collected to meet their daily domestic demands during the rainy season. A factor that can affect this is the perception of the rainwater for drinking as some users reported to use other sources for rainwater. This can increase the amount of months that were reported where water is collected from other sources, regardless if they had sufficient rainwater supply.

Most of the survey respondents were female. This was due to the surveys being carried out from 9-5pm when most of the men are away from their homes working. Even where there was a male present the women were more likely to participate due to the relationship and trust I had built with them throughout the course of the Peace Corps project implementation phase. This can present gender bias but on a minimal scale and I do not believe it has impact on the results and conclusion of this study.

The perception and knowledge of rainwater quality can impact the user's decision in using rainwater for potable uses. The behavior of the user can change when given sufficient information and knowledge as inclusion in the decision making process. Users tend to refuse rainwater use particularly for drinking and cooking purposes on the basis of perceived poor rainwater quality and acclimated use of other water sources, where most reported to use the well water for drinking. This can be linked to low TDS, which implies 
lower mineral content concentration and can impact taste, where mineral-rich water is more preferable (WHO, 2007). As a Peace Corps volunteer, I held workshops for all the DRWH participants in the program, explaining that rainwater is the cleanest water source. Their other water sources had been reported to contain higher levels of coliform, which was diffused to the community, with implications to their health. Although behavioral change was the most challenging aspect of the project, with the capacity building events and the use additional treatment prior to consumption, nearly $3 / 4$ of the respondents reported to now use rainwater for drinking. Of those who had a poor perception of rainwater it did not correlate to whether they used rainwater for drinking. Although there were few who reported poor perceptions of rainwater, those who did seemed to have been affected by the smell and taste and not the odor.

The knowledge and skills of the user receiving or constructing the tank are crucial to ensure a system will have a long life expectancy and that it is maintained properly aiding in the integrity of the infrastructure and the rainwater quality. Most of the male population of the community works in construction, meaning they have the technical knowledge and capacity to build and maintain the DRWHS. This can be seen through the existence of current DRWHS (10 total) that have lasted over 10 years. As part of the implementation of the project, local men were the local experts and were the primary ones constructing the storage tanks, because of their knowledge and skills. Another project objective required the involvement from the women of each household in the construction process. This helps women understand how to maintain the systems since they are primarily the ones cleaning the roofs and the cisterns frequently. 


\subsection{Water Quality Feasibility}

The water quality levels are suitable for non-potable uses, however further treatment is required to ensure there is no fecal contamination. Overall, the physiochemical water quality parameters were within the WHO guidelines (2008), with the exception of $\mathrm{pH}$ and two TDS values; even these were still acceptable for potable use. Overall, the $\mathrm{pH}$ was more alkaline, which has been linked to the tank and roof material, showing that concrete (the primary roof material) could attribute to the $\mathrm{pH}$ values. From Quek \& Förster (1993), it is reported that dissolution of calcium carbonate from the concrete can increase the $\mathrm{pH}$ (Adler et al., 2013). All the parameters measured for physiochemical characteristics are consistent with other rooftop rainwater harvested.

There was some microbiological contamination in the samples. This was most prevalent with HPC count, and only a small contamination of coliform bacteria. There were coliform bacteria detected in 4 out of the 17 users rainwater supply. The HPC and coliform are comparable to other roof-top rainwater harvested studies, where coliform bacteria count is lower in this community as compared to other study locations. The user maintenance showed to play a role in the amount of coliform and HTP count, implying that the more frequent the tank and cistern are cleaned, means better water quality.

\subsection{Technical Feasibility}

Under all scenarios DRHWS are not suitable for a year round supply for all community members, given the catchment size capacity and current household demand. Through the water balance model application for future use, the mean annual precipitation in San Jose Xacxamayo is said to increase over all A1, A2, and b1 scenarios. 
The future precipitation scenarios projected that precipitation will increase, seeming highly unlikely in comparison with the current and past rainfall data. This finding might be attributed to the insufficient scaling in The Climate Wizard Tool, suggesting that a regional scale model (50km resolution) is not ideal for estimating future scenarios for DRWHS reliability. Regardless, this model can give a conceptual reference of the temporal variability that could occur, however in this case the current seasonality does not differ from future scenarios. For water management and planning, it is still important to consider future conditions even with the uncertainties. To improve upon the current study, I would suggest the development of a more accurate downscaling model, if additional resources were available. Another alternative for future studies would be to take into account a percent increase or decrease of rainfall based on literature provided for the area, and use that information in a simulation model.

In order to improve the reliability of DRWHS, rooftops catchment sizes should be increased to a size of $150 \mathrm{~m}^{2}$ to meet the average demand of approximately $50 \mathrm{l} / \mathrm{c} / \mathrm{d}$. This suggestion can potentially be met by rooftop expansion or harnessing water from a neighboring household that has excess supply for a given month. The average roof size was $\sim 70 \mathrm{~m}^{2}$, thus to reach sufficient supply most roof would need to be doubled in size. This poses an issue for some houses that are in close proximity to neighboring houses. Other houses have sufficient land to expand their house and the technical capacity.

Although the community average demand is low, they can further conserve what water resources they utilize to alleviate some of the pressure on new water supplies. One suggestion is grey water use, which is not a current practice. For instance, water used to 
wash dishes can be used directly for irrigating small gardens. The water that is utilized should be conserved in transporting and usage. In addition domestic water uses for rooftop rainwater harvesting can be limited to certain activities particularly potable uses (cooking and drinking) and some non-potable uses (washing dishes). However, in this case and additional water source would be required as rainwater harvesting would be a supplemental source. 


\section{CONCLUSION}

The aim of this study was to examine the sustainability of DRWHS in a semi-arid, rural area of Mexico. This was carried out through an assessment of social, physical, and technical feasibility components of the DRWHS of existing systems in San Jose Xacxamayo. The main overall finding was that the social and physical feasibility were met and that there exists a technical feasibility barrier to provide sufficient water supply under current and future precipitation patterns. This is due to the fact that the average roof size of the participants $\left(70.4 \mathrm{~m}^{2}\right)$ was not sufficient to capture and store adequate year round water supply of the average annual demand $\left(87.9 \mathrm{~m}^{3}\right)$.

Through social assessment, I found that perception plays a role in domestic water application for potable use regardless of water supply necessities. Although difficult, cultural behaviors and attitudes of rainwater can sometimes be changed through education, which can impact the adoption of the technology. In addition, if there is local knowledge or skills, or willingness to learn, these conditions further enhance the reliability of DRWHS by reducing required maintenance and ensuring water health. There is potential to provide acceptable drinking water if the maintenance and tank materials are adhered to. Most of the parameters measured fell within WHO guidelines, however given the presence of microbiological contamination, further treatment before consumption is required. In the case of San Jose Xacxamayo most members have adapted simple treatment technologies (ceramic filter with silver colloidal lining) that address current water quality analyses yielding water that meets WHO drinking water guidelines. 
The main issue to unreliability of DRWHS as a result of this study was the technical feasibility. The technical feasibility shows the sensitivity of DRWHS to rainfall input on across three temporal scales (current, mid-century, end of century). In the technical feasibility it was found that under the given conditions the DRWHS were not reliable for all users year round, only during the rainy season (May-October). DRWHS should be viewed as a supplemental water source to users or provided the information, appropriate changes can be made to alter the supply that their current RWH system can provide to meet their annual water demand. In this case given the current demand and rainfall input, the roof requirement to meet the average demand would be $150 \mathrm{~m}^{2}$.

This research dissects sustainability of DRWHS through the social, physical, and technical components. This has shown the factors (culture and beliefs, economic costs, and local skill level) that can act as barriers to successful adoption and implementation of RWH for all domestic uses (potable and non-potable). Community involvement and contribution in the diagnostic, design, and implementation of water provisions was crucial in the successful implementation. These factors should be further examined and expanded upon in similar regions to provide more development in this area. Water planners, mangers, and communities can draw upon best implementation practices for social feasibility. For physical feasibility future water studies should include heavy metal analyses as well as physiochemical and bacteriological to assess the overall water health. Many studies have showed hypothetical water analyses of controlled DRHWS but focus should be on existing systems in communities in order to further community knowledge of the local water health and help improve their livelihood. The presence of tannins 
should be tested when chlorine has been used as a disinfectant as this has the potential to cause cancer. If other water sources exists in the community the same water analyses should be carried out to give knowledge of their safest water source, potentially changing social behaviors and increasing DRHWS adoption. For technical feasibility assessments, future precipitation patterns should continue to be considered in future studies and for water planners. A substantial limitation to this study was the method used to predict future precipitation patterns, which had a large spatial resolution and reported there would be an increased amount of rainfall, which may not the case for this community. For future studies, a water balance method with an appropriate regional scale analysis should be used or a percent change of precipitation in order to predict with high certainty the reliability of the DRWHS.

\subsection{Peace Corps Reflections}

Master International (MI) students are advised to select a thesis that can be integrated into the Peace Corps work the volunteer carries out. In order to develop and formulate my thesis I first had to focus and work on my Peace Corps projects to assess what was technically and financial feasible for my thesis work. This section will review challenges and lessons learned from both my Peace Corps work in DRWHS implementation and as a MI student.

\section{DRWHS Implementation}

There were many successes and several obstacles I faced along the way of the implementation of DRWHS in San Jose Xacxamayo, Mexico. Two of the main successes form this project were: 1) successful implementation and function of 82 DRWHS of 
$10 \mathrm{~m}^{3}$ capacity and 2) behavioral change of participants of rainwater now being acceptable to drink. These successes are primarily attributed to developing trust with the community by completing small-scale successful projects and getting to know the community members. The agency I worked for, SMASP, had already completed small gardens with the community before I arrived. Thus the community had established trust with the agency and the projects they conduct. I gained trust and developed relationships within the community through my time spent getting to know residents by: eating with them, going on local excursions to nearby waterfalls, and having an open dialogue and communication with them about their culture and lives.

Other key factors of the success of the systems and their durability are community participation in the design, implementation, and maintenance of DRWHS and transfer of knowledge through workshops. The community already had the interests and established that DRWHS would be beneficial to their water challenges. Thus, providing incentives and requirements helped to ensure everyone was fully participating. For instance, establishing a time and place for the workshop that will not interfere with the participants daily activities was critical. Also it was established from the beginning that those who miss the workshops would have to contribute more money, which incentivized the participants to be there and on time.

Although the overall project was a success, there were obstacles faced along the way. Three primary challenges I faced in the process of the implementation were 1) insufficient funds to have the whole community benefiting 2) lack of institutional support 
in some aspects 3) inability to break paternalistic relationship between the government and the communities.

It is important to be realistic from the beginning of the project and know that not everyone in the community is likely to benefit. This is something I had not considered in terms of the community conflicts that could arise. Although most of the conflicts were internal, they should be noted and other community members informed why they are asked to participate. In my work, only 82 out of $\sim 200$ households were recipients of DRWHS. I tried to benefit people who had no DRWHS and then help those who had good reputations for working and participating in past projects in their participation of the implementation of the projects and meeting and workshops.

I recommend that future volunteers realize that others may not be fully interested or willing to help out in the projects that Peace Corps volunteers carry out even when they say they are or have committed to help. I had a supportive and reliable counterpart in my agency however, a few of my coworkers were not as helpful. Thus it is recommended that the volunteer is ensuring that people are completing the work they promised and set certain deadlines to ensure the project is ahead of schedule. Written contracts and minutes of meetings are also helpful to prevent miscommunication.

Paternalistic relationships between the government and communities are prevalent throughout Mexico. Most communities expect handouts from the government whether or not it is something they need. This mentality can hinder economic progress and their livelihoods. DRWHS are helpful for the community I worked in even if they were not receiving rain year round because they use the systems to store purchased water. Those 
who were not recipients from these projects I advised they could attend the workshops in order to install their own system independently. Most of the community members have the technical skills to do so and although some had financial obstacles $\left(10 \mathrm{~m}^{3}\right.$ system cost $\sim \$ 400)$ it can still be accomplished over a year's time or less. I advised people on ways they could save money to help finance their own system such as cutting back on the amount of soda they drink (which for most households is at least 1 liter a day costing $\sim 1$ ) and to recycle the plastic bottles they have for money. However, some community members were not receptive to these ideas and were only seeking government aid and did not want to contribute their time or money. This has shown to be not effective in the jaguey that was established in the community by the local government in 2005 . This was planned, implemented, and financed through the local government alone. Currently, the system is not in use and sits collecting water in a community that is water scarce.

\section{Master's International Student}

The challenge with being a MI student in the Peace Corps is that thesis is advised to be in relation to your Peace Corps work, which in many cases the projects do not get initiated until after a year in their site. This puts pressure to carry out a thesis in the last year you are there. The limited time for thesis planning can cause financial or technical constraints.

A few recommendations I have for future MI students are to establish relationships with people in your field of interest and incorporate your thesis work and Peace Corps project in the financial planning stages. When I first arrived to Puebla, I sought out to audit a class at a local university to improve my Spanish and to meet people 
in my area of interest. The class enabled me to form a connection with the professor of the sustainability course, Dr. Mangas. He later helped me in one of my Peace Corps projects and he allowed me to use his laboratory for my water analyses. He guided me on where to purchase laboratory material and trained me on some of the equipment I was to use. In addition he was a great resource to further understand the water politics and challenges faced in Puebla. In addition, that class also allowed me to form a friendship with a biology student, Marce, who was the workshop facilitator in my Peace Corps work.

In addition it is highly recommended to incorporate the technical and financial requirements of the thesis into the Peace Corps work. In my case, the projects were implemented from four different funding sources, two local and two international. The two international sources, USAID and Peace Corps Partnership Program, are available for Peace Corps volunteer use. Thus the water analyses equipment and testing that my thesis required was written into my project proposal for DRWHS implementation from these two funding sources. This is also a way to ensure that I am relating results back to the community to further their understanding of their rainwater quality and how they can improve upon it through maintenance measures. 


\section{REFERENCES}

Abbott, S.E., Douwes J., Caughley B.P. (2006). A survey of the microbiological quality of roof-collected rainwater of private dwellings in New Zealand. In: Proceedings of the 2006 Water International Conference, New Zealand, pp. 1-24.

Abdulla, F. A., \& Al-Shareef, A. W. (2009). Roof rainwater harvesting systems for household water supply in Jordan. Desalination, 243(1), 195-207.

Adler, I., Hudson-Edwards, K. A., \& Campos, L. C. (2013). Evaluation of a silver-ion based purification system for rainwater harvesting at a small-scale community level. Journal of Water Supply: Research and Technology-AQUA,62(8), 545-551.

Alam, R., Munna, G., Chowdhury, M. A. I., Sarkar, M. S. K. A., Ahmed, M., Rahman, M. T., \& Toimoor, M. A. (2012). Feasibility study of rainwater harvesting system in Sylhet City. Environmental monitoring and assessment, 184(1), 573-580.

Alcamo, J., Henrichs, T., and Rosch, T. (2000). World Water in 2025. Center for Environmental Systems Research, University of Kasse.

Arnell, N. W. (2004). Climate change and global water resources: SRES emissions and socio-economic scenarios. Global environmental change, 14(1), 31-52.

Baguma, D., Loiskandl, W., Darnhofer, I., Jung, H., \& Hauser, M. (2010). Knowledge of measures to safeguard harvested rainwater quality in rural domestic households. Journal of water and health, 8(2), 334-345.

Bajracharya, D. and Deverill, P. (2001). Developing a poverty focused, demand responsive approach. In WEDC CONFERENCE (Vol. 27, pp. 79-82).

Barron, J. (2009). Rainwater harvesting: a lifeline for human well-being. UNEP/Earthprint.

Bates, B.C., Kundzewicz, Z.W., Wu, S. and Palutikof, J.P. (2008). Climate Change and Water. Technical Paper of the Intergovernmental Panel on Climate Change, IPCC Secretariat, Geneva, 210 pp.

Chang, M., McBroom, M. W., \& Beasley, R. S. (2004). Roofing as a source of nonpoint water pollution. Journal of environmental management, 73(4), 307-315.

Choudhury, I \& Vasudevan, L. (2003). Factors of biological contamination of harvested rainwater for residential consumption. Hawaii International Conference on Social Sciences. Honolulu, Hawaii: University of Hawaii. June 2003. [WWW document]. URL http://www.watercache.com/docs/rwquality1.pdf.

Crow B. (2001). Water: gender and material inequalities in the global south. University of California, Santa Cruz. 
Domènech, L., Heijnen, H. and Saurí, D. (2012), Rainwater harvesting for human consumption and livelihood improvement in rural Nepal: benefits and risks. Water and Environment Journal, 26: 465-472. doi: 10.1111/j.1747-6593.2011.00305.x

Doria, M.D.F (2010). Factors influencing public perception of drinking water quality. Water policy 12:1-19.

Fewkes, A., \& Butler, D. (2000). Simulating the performance of rainwater collection and reuse systems using behavioural models. Building Services Engineering Research and Technology, 21(2), 99-106.

Gardner, T. \& Vieritz, A. (2010). The role of rainwater tanks in Australia in the twenty first century. Architectural Science Review, 53(1), 107.

Gould, J. (1992). Rainwater Catchment Systems for House- hold Water Supply, Environmental Sanitation Reviews, No. 32, ENSIC, Asian Institute of Technology, Bangkok.

Gould, J. and Nissen-Petersen, E. (1999). Rainwater Catchment Systems for Domestic Supply: Design, Construction and Implementation. Intermediate Technology Publications, London, UK.

Gould, J. (1999). Is rainwater safe to drink? A review of recent findings. In: Proceedings of the 9th International Conference on Rain Water Cistern Systems, Brazil, p. 9.

Heijnen, H., \& Pathak, N. (2006). Rainwater Harvesting Quality, health and Hygiene Aspects. Making Rain Water Every Body’s Business, 21.

Helmreich, B., \& Horn, H. (2009). Opportunities in rainwater harvesting. Desalination, 248(1), 118-124.

Jenkins, D., Pearson, F., Moore, E., Sun, J. K. \& Valentine, R. (1978). Feasibility of rainwater collection systems in California. Contribution No. 173, Californian Water Resources Centre, University of California, USA.

IPCC. Climate change (2000): the science basis. Contribution of Working Group II to the IPCC third assessment report 2001. UK: Cambridge University Press; 2000.

Islam, M. M., Chou, F. F., Kabir, M. R., \& Liaw, C. H. (2010). Rainwater: A potential alternative source for scarce safe drinking and arsenic contaminated water in Bangladesh. Water resources management, 24(14), 3987-4008.

Imteaz, M.A., Adeboye, O.B., Rayburg, S., \& Shanableh,A.(2012). Rainwater harvesting potential for southwest Nigeria using daily water balance model. Resources, Conservation and Recycling, Volume 62, Pages 51-55, ISSN 0921-3449. 
Kim, K., \& Yoo, C. (2009). Hydrological modeling and evaluation of rainwater harvesting facilities: case study on several rainwater harvesting facilities in Korea. Journal of Hydrologic Engineering, 14(6), 545-561.

Liaw C.H., \& Tsai Y.L. (2004). Optimum Storage volume of rooftop rainwater harvesting systems for domestic use Journal of the American Water Resources Association: Vol. 40. 901-912.

Ludwig, Art. (2005). Water Storage. Tanks, Cisterns, Aquifers, and Ponds. Oasis Design.

Mays, L., Antoniou, G.P., \& Andreas, A.N. (2013). History of water cisterns: legacies and lessons. Water 5.4: 1916-1940.

Meera, V. \& Ahammed, M. M. (2006). Water quality of rooftop rainwater harvesting systems: a review. Journal of Water Supply: Research and Technology, AQUA. 55, 257-268.

Metre, V, P, C, \& Mahler, B, ], (2003). The contribution of particles washed from roof tops to contaminant loading to urban streams, Chemosphere 52, 1121-11M.

Mun, J.S. and Han, M.Y. (2012). Design and operational parameters of a rooftop rainwater harvesting system: Definition, sensitivity and verification. Journal of Environmental Management, Volume 93, Issue 1, Pages 147-153, ISSN 0301-4797.

Mutekwa, V., \& Kusangaya, S. (2007). Contribution of rainwater harvesting technologies to rural livelihoods in Zimbabwe: The case of Ngundu ward in Chivi District. Water SA, 32(3), 437-444.

Mwenge Kahinda J, Taigbenu Ae, and Boroto, R.J. (2007). Domestic rainwater harvesting to improve water supply in rural South Africa. Journal Physics and Chemistry of the Earth 32 (15-18) 1050-1057.

Ndiritu, J., Odiyo, J. O., Makungo, R., Ntuli, C., \& Mwaka, B. (2011). Yieldreliability analysis for rural domestic water supply from combined rainwater harvesting and run-of-river abstraction. Hydrological Sciences Journal-Journal des Sciences Hydrologiques, 56(2), 238-248.

Olaoye, R. A., \& Olaniyan, O. S. (2012). Quality of Rainwater from Different Roof Material. International Journal of Engineering and Technology, 2(8).

Palla A., Gnecco I. and Lanza L.G. (2011). Non-dimensional design parameters and performance assessment of rainwater harvesting systems [Article] // Journal of Hydrology. Vol. 40. - pp. 65-76. 
Peter-Varbanets, M., Zurbrügg, C., Swartz, C., \& Pronk, W. (2009).

Decentralized systems for potable water and the potential of membrane technology. water research, 43(2), 245-265.

Pushpangadan, K, \& Sivanandan, P. K. (2001). Technology, quality and cost of water from DRWH - a case study in Kerala, India.

Sazakli, E., Alexopoulos, A., Leotsinidis, M., (2007). Rainwater harvesting, quality assessment and utilization in Kefalonia Island, Greece. Water Research 41, 2039 2047.

Schets, F., Italiaander, R., Van Den Berg, H. H. J. L., \& de Roda Husman, A. (2010). Rainwater harvesting: quality assessment and utilization in The Netherlands. Journal of water and health, 8(2), 224-235.

Sheat A. (1992). Public perception of drinking water quality. Should we care? Paper presented at the New Zealand Water Supply and Disposal Association Annual Conference.

Simmons, G., Hope, V., Lewis, G., Whitmore, J. \& Gao, W. (2001). Contamination of roof-collected rainwater in Auckland, New Zealand. Wat. Res. 35, $1518-1524$.

Texas Water Development Board (TWDB). (2005). The Texas Manual on Rainwater Harvesting. Third Edition. Austin, Texas. Hari J. Krishna, P.E. p. 10.

Technology Unit (DTU) (2002). Very Low-Cost Domesti Roofwater Harvesting in the Humid Tropics: Existing Practice. Roofwater Harvesting Research Programme University of Warwick Domestic

Thomas, T. H., \& Martinson, D. B. (2007). Roofwater harvesting: a handbook for practitioners. In IRC Technical paper series (No. 49). IRC.

United Nations (UN). (2007). Coping with water scarcity: challenge of the twenty-first century. 2007 World Water Day.

UNEP/IETC (United Nations Environment Programme/ International Environmental Technology Centre). (1998). Sourcebook of alternative technologies for freshwater augmentation in Africa. UNEP, Nairobi, Kenya.

United Nations Environmental Programme (1997). Rainwater Harvesting from rooftop Catchments. Retrieved from The Sourcebook of Alternative Technologies for Freshwater46Augmentation in Latin America and the Caribbean.

Vasudevan, P., Pathak, N., \& Mittal, P. K. (2000). DRWH and insect vectors: a literature review. Sub programme C: Health Implications. Milestone, 2. 
Veenhuizen, R. V., \& Prieto-Celi, M. (2000). Manual de captación y aprovechamiento del agua de lluvia, experiencias en América Latina. Santiago, CL. Oficina regional de la FAO (Organización de las Naciones Unidas para la Agricultura y la Alimentación). FOODAGRI SANTIAGO. 224p.

Ward, S., Memon, F., \& Butler, D. (2010). Rainwater harvesting: model-based design evaluation.

WHO. (2003). Guidelines for Drinking-water Quality, World Health Organization, Geneva.

WHO. (2008). Guidelines for Drinking-water Quality-Incorporating First Addendum. Recommendations, 3rd edition. Vol. 1. World Health Organization, Geneva, Switzerland.

WHO. (2010). World Water Day, water for health, WHO Press. World Health Organization, Geneva, Switzerland.

WHO. (2012). Global Status. WHO Press, World Health Organization, Geneva, Switzerland.

Zhu, K., Zhang, L., Hart, W., Liu, M., Chen, H., (2004). Quality issues in harvested rainwater in arid and semi-arid Loess Plateau of Northern China. Journal of Arid Environments 57, 487-505. 


\section{APPENDICES}

\section{Appendix A: Survey}

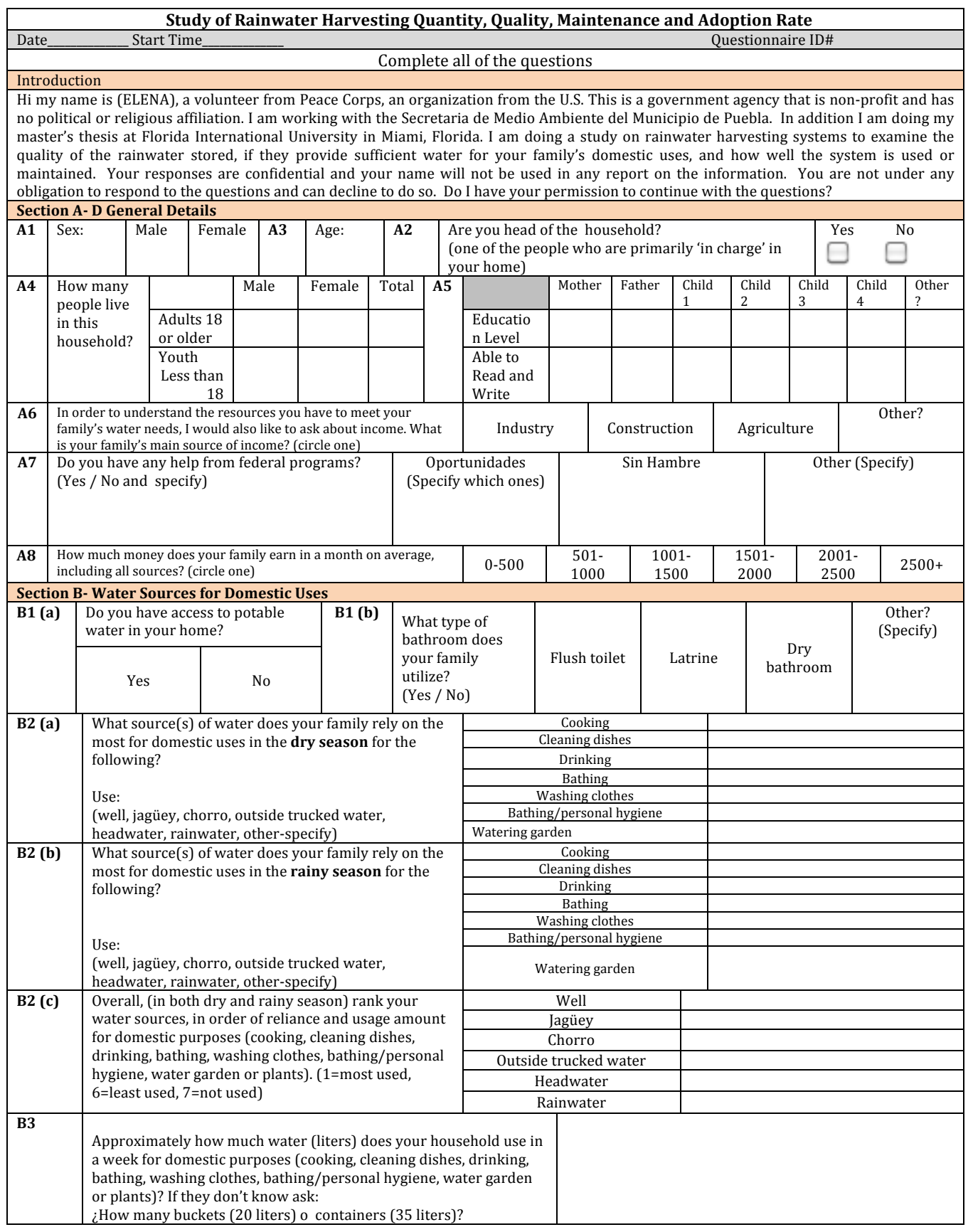




\begin{tabular}{|c|c|c|c|c|c|c|c|c|c|c|c|c|c|c|c|c|c|}
\hline B4 (a) & \multicolumn{7}{|c|}{$\begin{array}{l}\text { If you collect from a well, 'chorro' or headwater } \\
\text { tanks: how many days a week does your family the } \\
\text { collect water? } \\
\text { (Select one number of the following): } 1-7 \text { ) }\end{array}$} & & & $\begin{array}{l}\text { B4 } \\
\text { (b) }\end{array}$ & \multicolumn{6}{|c|}{$\begin{array}{l}\text { If you collect from a well, 'chorro' or headwater } \\
\text { tanks: how many months out of the year does } \\
\text { your family the collect water? } \\
\text { (Select one number of the following): 1-7) }\end{array}$} & \\
\hline \multirow[t]{2}{*}{ B5 (a) } & \multicolumn{5}{|c|}{$\begin{array}{l}\text { Do you collect water from a } \\
\text { well? (If no skip to B6) }\end{array}$} & \multirow[t]{2}{*}{$\begin{array}{l}\text { B5 } \\
\text { (b) }\end{array}$} & \multirow{2}{*}{\multicolumn{3}{|c|}{$\begin{array}{l}\text { How much time is } \\
\text { spent collecting water } \\
\text { from a well in one } \\
\text { trip? }\end{array}$}} & \multirow{2}{*}{\multicolumn{2}{|c|}{$0-19 \min$}} & \multirow{2}{*}{\multicolumn{2}{|c|}{$\begin{array}{c}20- \\
39 \mathrm{~min}\end{array}$}} & \multirow{2}{*}{$\begin{array}{c}40- \\
59 \mathrm{~min}\end{array}$} & \multirow{2}{*}{\multicolumn{2}{|c|}{$\begin{array}{l}60- \\
89 \min \end{array}$}} & \multirow{2}{*}{$\begin{array}{l}\text { Mas de } 90 \\
\quad \text { min }\end{array}$} \\
\hline & & Yes & & No & & & & & & & & & & & & & \\
\hline \multirow[t]{2}{*}{ B6 (a) } & \multicolumn{5}{|c|}{$\begin{array}{l}\text { Do you collect water from the } \\
\text { 'chorro'? (If no skip to B7) }\end{array}$} & \multirow[t]{2}{*}{$\begin{array}{l}\text { B6 } \\
\text { (b) }\end{array}$} & \multirow{2}{*}{\multicolumn{3}{|c|}{$\begin{array}{l}\text { How much time is } \\
\text { spent collecting water } \\
\text { from the 'chorro' in } \\
\text { one trip? }\end{array}$}} & \multirow{2}{*}{\multicolumn{2}{|c|}{$0-19 \min$}} & \multirow{2}{*}{\multicolumn{2}{|c|}{$\begin{array}{c}20- \\
39 \mathrm{~min}\end{array}$}} & \multirow{2}{*}{$\begin{array}{c}40- \\
59 \min \end{array}$} & \multirow{2}{*}{\multicolumn{2}{|c|}{$\begin{array}{l}60- \\
89 \min \end{array}$}} & \multirow{2}{*}{$\begin{array}{l}\text { Mas de } 90 \\
\quad \min \end{array}$} \\
\hline & & Yes & & No & & & & & & & & & & & & & \\
\hline \multirow[t]{2}{*}{ B7 (a) } & \multicolumn{5}{|c|}{$\begin{array}{l}\text { Do you collect water from the } \\
\text { headwater tank? (If no skip to } \\
\text { B8) }\end{array}$} & \multirow[t]{2}{*}{$\begin{array}{l}\text { B7 } \\
\text { (b) }\end{array}$} & \multirow{2}{*}{\multicolumn{3}{|c|}{$\begin{array}{l}\text { How much time is } \\
\text { spent collecting water } \\
\text { from the headwater } \\
\text { tank in one trip? }\end{array}$}} & \multirow{2}{*}{\multicolumn{2}{|c|}{$0-19 \mathrm{~min}$}} & \multirow{2}{*}{\multicolumn{2}{|c|}{$\begin{array}{c}20- \\
39 \mathrm{~min}\end{array}$}} & \multirow[t]{2}{*}{$\begin{array}{c}40- \\
59 \min \end{array}$} & \multirow{2}{*}{\multicolumn{2}{|c|}{$\begin{array}{c}60- \\
89 \min \end{array}$}} & \multirow[t]{2}{*}{$\begin{array}{l}\text { Mas de } 90 \\
\quad \text { min }\end{array}$} \\
\hline & & Yes & & No & & & & & & & & & & & & & \\
\hline \multirow[t]{2}{*}{ B8 (a) } & \multicolumn{8}{|c|}{$\begin{array}{l}\text { Who is the main person responsible for collecting } \\
\text { water in the household? }\end{array}$} & \multirow[t]{2}{*}{ B8 (b) } & & & & & & & & \\
\hline & Mot & & Fat & & & Child & \begin{tabular}{l|l} 
Oth \\
Spe
\end{tabular} & & & & $\begin{array}{l}\text { Wha } \\
\text { the } \\
\text { re }\end{array}$ & $\begin{array}{l}\text { is the } \\
\text { main p } \\
\text { sponsil }\end{array}$ & $\begin{array}{l}\text { e age of } \\
\text { person } \\
\text { ible? }\end{array}$ & $0-9$ & $\begin{array}{l}10- \\
17\end{array}$ & $18-25$ & $25+$ \\
\hline B9 (a) & $\begin{array}{l}\text { Do yo } \\
\text { water } \\
\text { truck } \\
\text { skip t }\end{array}$ & $\begin{array}{l}\text { purchase } \\
\text { rom outsi } \\
\text { l water (II } \\
\text { B10) }\end{array}$ & & & & $\begin{aligned} \text { Wh } \\
\text { pur }\end{aligned}$ & $\begin{array}{l}\text { at season } \\
\text { chase the } \\
\text { cucked w }\end{array}$ & $\begin{array}{l}\text { you } \\
\text { itside } \\
\text { er? }\end{array}$ & & $\begin{array}{l}\text { B9 } \\
\text { (c) }\end{array}$ & $\begin{array}{r}\text { How } n \\
\text { pay } f \\
\text { truck }\end{array}$ & $\begin{array}{l}\text { nuch do } \\
\text { or out } \\
\text { ed wat } \\
\text { (MXD) }\end{array}$ & $\begin{array}{l}\text { do you } \\
\text { tside } \\
\text { ater? }\end{array}$ & B9 (d) & $\begin{array}{l}\text { Wha } \\
\text { outs } \\
\text { y } \\
\text { (spe }\end{array}$ & $\begin{array}{l}\text { at is the si } \\
\text { ide truck } \\
\text { jou purch } \\
\text { ecify the }\end{array}$ & $\begin{array}{l}\text { size of the } \\
\text { ked water } \\
\text { hase? } \\
\text { amount) }\end{array}$ \\
\hline & Yes & No & & & & rainy & dry & both & & & & & & & & & \\
\hline $\begin{array}{l}\text { B9 } \\
\text { (e) }\end{array}$ & $\begin{array}{l}\text { How o } \\
\text { water? }\end{array}$ & en do you & buy $o$ & & truc & ked & $\begin{array}{l}\text { Onc } \\
\text { mor }\end{array}$ & & $\begin{array}{l}\text { Once e } \\
\text { thre } \\
\text { mon }\end{array}$ & $\begin{array}{l}\text { every } \\
\text { ee } \\
\text { ths }\end{array}$ & $\begin{array}{l}\text { Once } \\
\text { six m }\end{array}$ & $\begin{array}{l}\text { every } \\
\text { onths }\end{array}$ & & nce a year & & Other? -S & Specify \\
\hline $\begin{array}{l}\text { B10 } \\
\text { (a) }\end{array}$ & $\begin{array}{l}\text { Do you } \\
\text { water } \\
\text { trucked } \\
\text { from th } \\
\text { headw } \\
\text { If no, sk } \\
\text { Section }\end{array}$ & $\begin{array}{l}\text { urchase } \\
\text { om } \\
\text { water } \\
\text { er tank } \\
\text { p to } \\
\text { jo }\end{array}$ & B10 & & & $\begin{array}{l}\text { at seasor } \\
\text { trucked v } \\
\text { headv }\end{array}$ & $\begin{array}{l}\text { do you p } \\
\text { rater fron } \\
\text { rater tank }\end{array}$ & $\begin{array}{l}\text { chase } \\
\text { he }\end{array}$ & \begin{tabular}{|l} 
B1 \\
$\mathbf{0}$ \\
(c)
\end{tabular} & $\begin{array}{r}\text { Hov } \\
\text { yo } \\
t \\
\text { wa } \\
\text { he } \\
\tan \end{array}$ & $\begin{array}{l}\text { w much } \\
\text { ou pay f } \\
\text { trucked } \\
\text { ater fro } \\
\text { the } \\
\text { eadwat } \\
\text { nk? (MX }\end{array}$ & & B10 (d) & & $\begin{array}{c}\text { Wha } \\
\text { truck } \\
\text { hea } \\
\text { pur } \\
\text { (spe }\end{array}$ & $\begin{array}{l}\text { tis the si } \\
\text { ed water } \\
\text { dwater ta } \\
\text { chase reg } \\
\text { cify the a }\end{array}$ & $\begin{array}{l}\text { ize of the } \\
\text { from the } \\
\text { tank you } \\
\text { gularly? } \\
\text { amount) }\end{array}$ \\
\hline & Yes & No & & & $\begin{array}{l}\mathrm{i} \\
\mathrm{n} \\
\mathrm{y}\end{array}$ & dry & & & & & & & & & & & \\
\hline $\begin{array}{l}\text { B10 } \\
\text { (e) }\end{array}$ & $\begin{array}{l}\text { How o } \\
\text { headn }\end{array}$ & $\begin{array}{l}\text { en do you } \\
\text { ter tank? }\end{array}$ & buy t & acke & d wa & ter from & & & $\begin{array}{l}\text { ice a } \\
\text { onth }\end{array}$ & & $\begin{array}{l}\text { nce } \\
\text { very } \\
\text { aree } \\
\text { onths }\end{array}$ & $\begin{array}{c}\text { Once } \\
\text { every } \\
\text { six } \\
\text { mont } \\
\text { hs }\end{array}$ & & nce a year & & Other? -S & Specify \\
\hline$\overline{B 11}$ & $\begin{array}{r}\mathrm{Ha} \\
\text { water }\end{array}$ & $\begin{array}{l}\text { e you or y } \\
\text { related dis }\end{array}$ & $\begin{array}{l}\text { our fa } \\
\text { eases }\end{array}$ & (W & $\begin{array}{l}\text { ver h } \\
\text { iich }\end{array}$ & $\begin{array}{l}\text { lad any } \\
\text { one (s)?) }\end{array}$ & & & & & & & & & & & \\
\hline
\end{tabular}




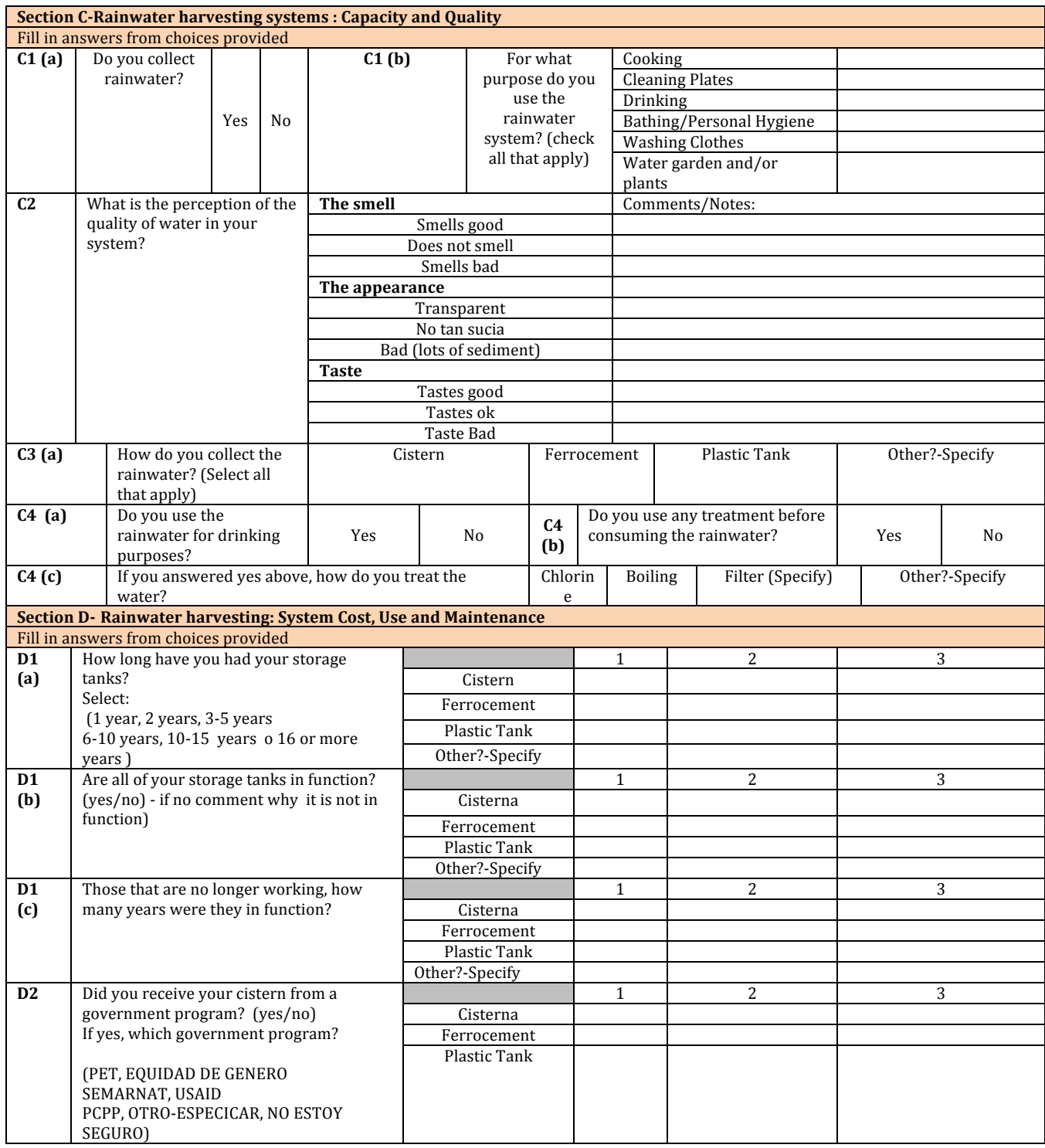




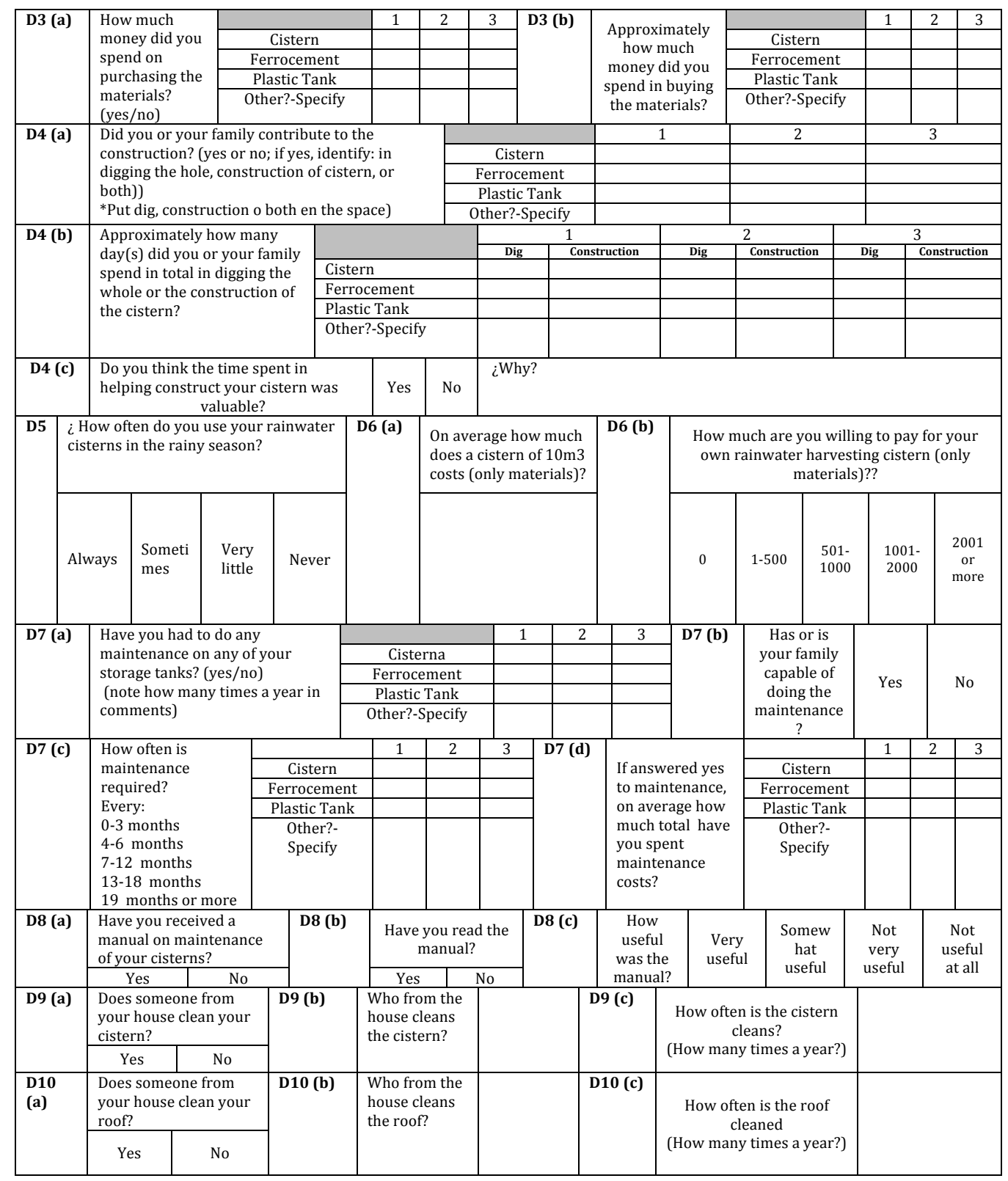


Appendix B: Water Quality Results

\begin{tabular}{|c|c|c|c|c|c|}
\hline $\mathbf{N}$ & $\operatorname{Temp}\left({ }^{\circ} \mathrm{C}\right)$ & pH & EC $(\mu S / \mathrm{cm})$ & TDS (ppm) & $\begin{array}{c}\text { Ammonia } \\
\text { (ug/l) }\end{array}$ \\
\hline 1 & 18.8 & 8.2 & 124 & 87 & 45 \\
\hline 2 & 19.1 & 9.48 & 64 & 45 & 90 \\
\hline 3 & 19 & 9.3 & 61 & 42 & 75 \\
\hline 4 & 18.6 & 10.42 & 176 & 123 & 62 \\
\hline 5 & 17.1 & 7.7 & 58 & 40 & 30 \\
\hline 6 & 19.4 & 8.46 & 71 & 49 & under \\
\hline 7 & 20.8 & 9.81 & 109 & 76 & 53 \\
\hline 8 & 20.5 & 8.77 & 148 & 104 & 33 \\
\hline 9 & 22.2 & 8.34 & 102 & 71 & 15 \\
\hline 10 & 21.6 & 8.11 & 110 & 77 & 21 \\
\hline 11 & 20.1 & 8.2 & 86 & 60 & 45 \\
\hline 12 & 21.1 & 8.17 & 113 & 79 & 18 \\
\hline 13 & 20.6 & 7.93 & 77 & 53 & 245 \\
\hline 14 & 20.2 & 7.95 & 33 & 23 & 179 \\
\hline 15 & 19.8 & 9.34 & 93 & 65 & under \\
\hline 16 & 18.9 & 7.93 & 100 & 70 & 97 \\
\hline 17 & 19 & 10.41 & 130 & 91 & 33 \\
\hline verage & 19.81 & 8.74 & 97.35 & 67.94 & 69.40 \\
\hline
\end{tabular}


Appendix C: Water Balance Model Inputs

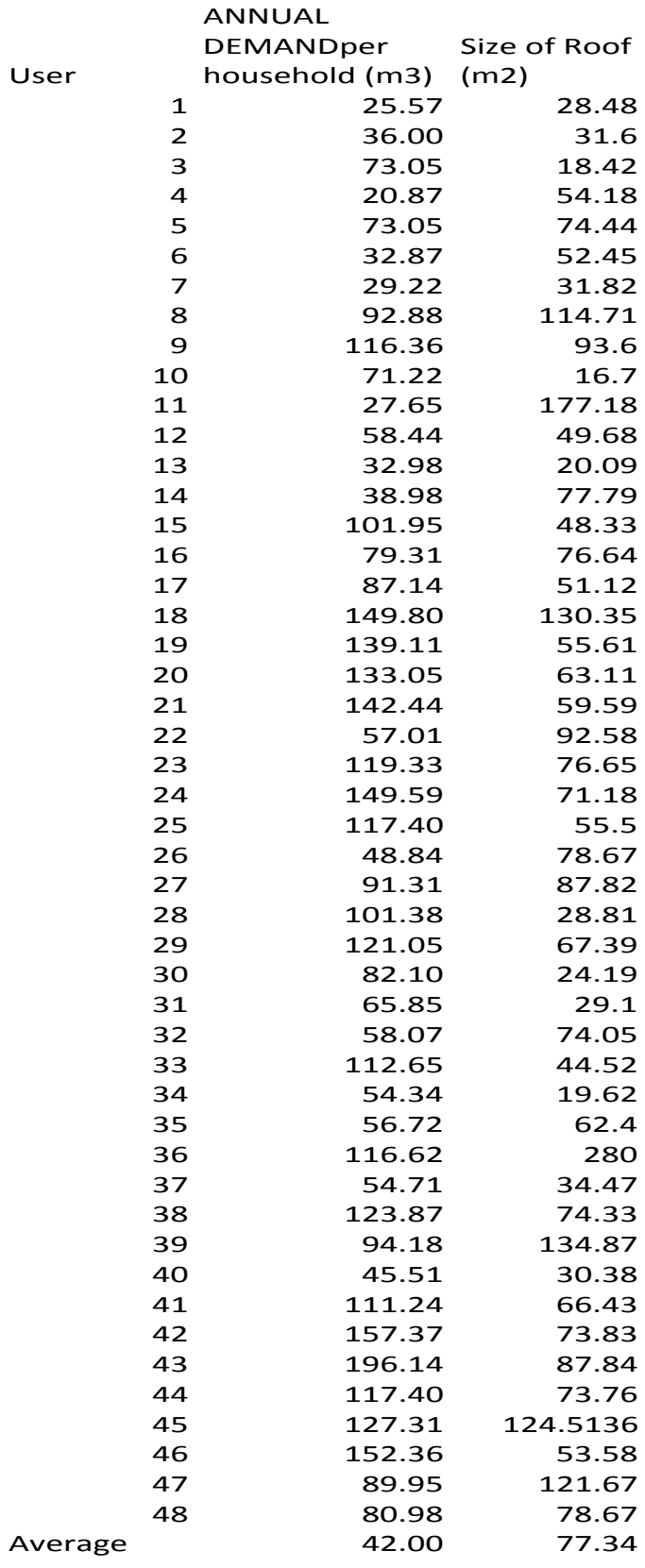


Appendix D: Example of Regional Scale Output from Climate Wizard Tool

Future Average Total Rainfall - 2046 to 2065

Model: Ensemble, SRES emission scenario: High (A2)

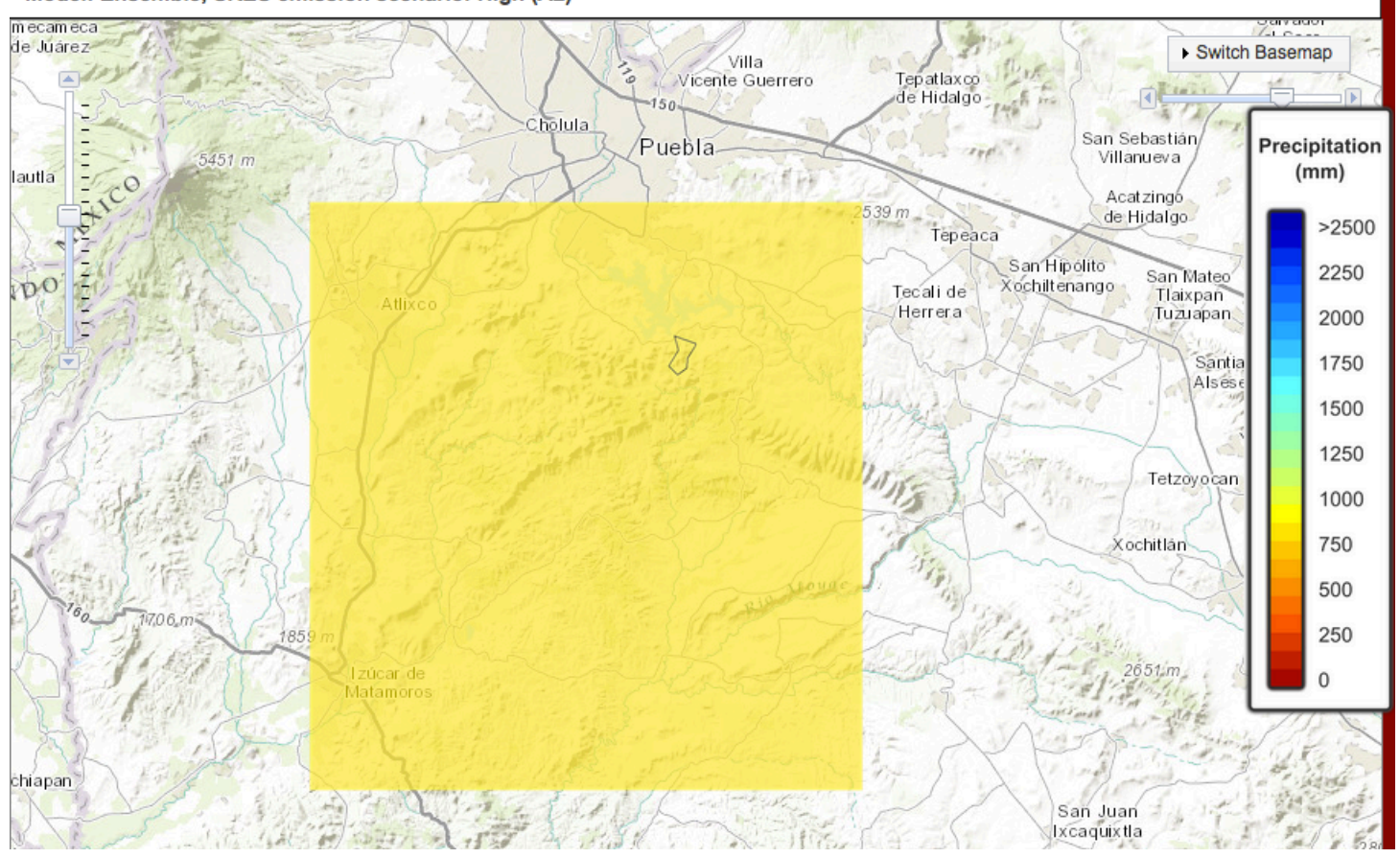


Appendix E: Water Balance Model Inputs

Monthly and Annual Average Preciptiation (mm)

January February March April May June July August September October November December Total

\begin{tabular}{|c|c|c|c|c|c|c|c|c|c|c|c|c|c|}
\hline Current & 10.80 & 6.90 & 8.20 & 26.80 & 78.30 & 143.70 & 113.50 & 115.40 & 145.40 & 58.40 & 11.90 & 5.40 & 724.7 \\
\hline Mid Century A2 & 7.12 & 6.18 & 8.02 & 18.95 & 79.37 & 174.57 & 127.45 & 151.81 & 186.90 & 82.37 & 21.28 & 6.76 & 870.79 \\
\hline Mid Century A1b & 6.02 & 6.93 & 10.19 & 22.41 & 70.54 & 177.43 & 134.43 & 154.00 & 186.93 & 85.58 & 21.88 & 6.26 & 882.61 \\
\hline Mid Century b1 & 8.02 & 7.12 & 12.01 & 22.96 & 92.04 & 185.03 & 144.11 & 145.04 & 174.94 & 77.52 & 20.64 & 7.29 & 896.72 \\
\hline End of Century A2 & 5.48 & 5.28 & 6.44 & 21.04 & 70.76 & 160.40 & 100.90 & 127.72 & 176.53 & 93.35 & 22.00 & 4.86 & 794.75 \\
\hline End of Century Alb & 7.14 & 6.59 & 10.24 & 23.93 & 76.48 & 164.56 & 116.54 & 149.77 & 188.08 & 90.36 & 17.82 & 6.66 & 858.18 \\
\hline End of Century b1 & 7.07 & 7.78 & 12.36 & 20.57 & 85.04 & 178.69 & 138.18 & 156.84 & 191.23 & 78.62 & 25.17 & 5.52 & 907.07 \\
\hline
\end{tabular}

